\title{
Late Pleistocene-Holocene History of Chaco-Pampa Sediments in Argentina and Paraguay
}

\author{
Wolfgang Kruck, Fabian Helms, Mebus A. Geyh, José M. Suriano, Hugo G. Marengo, Fernando Pereyra
}

\begin{abstract}
:
A substantially improved reconstruction of the Late Pleistocene-Holocene morphological and geological history of the Paraguayan Chaco and the Argentine Pampa Plain (Chaco-Pampa Plain) is presented. Due to the vast extension of the area, satellite images are the clue to synthesize previous and new multidisciplinary geoscientific results to set up a more reliable regional picture. For this synoptic view the interpretation of remote sensing data was complemented by ground investigation and physical age determinations. Luminescence ages (75 IRSL and $12 \mathrm{TL}$ ) of loess, loessoids and sands were determined to reconstruct the climatic history of the study area in the Marine Isotopic Stages (MIS) 3 to 1. Loess deposition dominated the period prior to MIS 2. For MIS 2 and MIS 1 the numerical ages of lacustrine and alluvial sediments intercalating the loess provide evidence for alternating humid and dry periods in the Chaco-Pampa Plain. Prevailing dry climate lasted from 8.5 to 3.5 ka (middle MIS 1) when sandy sediments deposited as dunes or filled palaeoriver beds. Temporarily limited phases of palaeoriver activity were related to sporadic torrential rainfall in the Andes Mountains.

Source regions of loess, loessoid and sandy deposits were localized in the south-western Pampa and the neighbouring Andean slopes and the Altiplano. These sediment were transported towards east and later northeast as reconstructed by the morphological features and remnants of past aeolian activity periods.
\end{abstract}

[Spätpleistozän-holozäne Geschichte der Chaco-Pampasedimente in Argentinien und Paraguay]

Kurzfassung: Eine erheblich verbesserte Rekonstruktion der spätpleistozänen/holozänen morphologischen und geologischen Geschichte des
paraguayischen Chaco und der argentinischen Pampa Ebene wird vorgestellt. Wegen der großen Ausdehnung des Gebietes
waren Satellitenbilder der Schlüssel, um frühere und neue interdisziplinäre geowissenschaftliche Ergebnisse zu einem verlässli-
cheren Bild zusammenzuführen. Für diesen synoptischen Überblick wurde die Interpretation von Fernerkundungsdaten durch
Geländeuntersuchungen und physikalische Altersbestimmungen ergänzt. Viele Lumineszenzalter (75 IRSL und 12 TL) von Löß,
lößähnlichen Sedimenten und Sanden wurden bestimmt, die bei der Rekonstruktion der Klimageschichte des Untersuchungs-
gebiets im Marinen Isotopen Stadium 3 bis 1 (MIS 3-1) beitragen.
Lößablagerungen überwiegen in der Zeit vor MIS 2. Die numerische Alter von lakustrinen und alluvialen Sedimenten, im
Löß zwischengelagert, belegen wechselnde feuchte und trockene Perioden in der Chaco/Pampa-Ebene im MIS 2 und MIS 1 .
Überwiegend trockene Bedingungen herrschten von 8.5 bis 3.5 ka BP (mittleres MIS 1), als Sande in Form von Dünen oder in
Paläoflussbetten abgelagert wurden. Zeitlich begrenzte Phasen extrem verstärkter Paläoflussaktivität im Mittelholozän wurden
auf sporadische Starkregenereignisse in den Anden zurückgeführt.
Die Ursprungsgebiete des Löß, der lößartigen Sedimente und der sandigen Ablagerungen wurden in der südwestlichen Pampa,
den benachbarten Andenabhängen und im Altiplano lokalisiert. Diese Sedimente wurden von dort nach Osten und später nach Nordosten transportiert, wie sich aus den morphologischen Mustern als Zeugnisse früherer äolischer Aktivität rekonstruieren ließ.

Key words: Pampa, Chaco, morphology, chronology, Pleistocene, Holocene, Loess

Addresses of authors: W. Kruck, Ginsterweg 16, D-29323 Wietze, Germany. E-Mail: w.kruck@t-online.de; F. Helms, BGR, Stilleweg 2, D-30655 Hannover, Germany. E-Mail: fabian-helms@gmx.de; M.A. Geyh, Rübeland 12, OT Bannetze, D-29308 Winsen, Germany. E-Mail: mebus. geyh@t-online.de; J.M. Suriano, H.G. Marengo, F. Pereyra, SEGEMAR, Avda.Roca 651, 1322 Buenos Aires, Argentina. E-Mail: canaleana@yahoo.com.ar, hugomarengo@gmail.com, fernap@mecon.gov.ar

\section{Introduction}

The Chaco-Pampa Plain extends from the central and northern lowlands of Argentina to the Paraguayan (and Bolivian) Chaco. It covers an area of more than $1500000 \mathrm{~km}^{2}$ and stretches from the Paraguay-Bolivian border in the north to the Río Colorado in the south (southern border of the Buenos Aires Province), from the Andean foot in the west to the Río Paraná, Uruguay and the Atlantic coast in the east. The surface is generally dipping to the east and south-east.

The climate is controlled by both semi-permanent southeastern Pacific anticyclones in the west and south-western Atlantic anticyclones in the east. Warm and humid air masses mainly originate from the Atlantic. Isohyets are nearly oriented north-northwest/south-southeast with decreasing rainfall to the west. Hence, the climate changes from subtropical to arid conditions from north-east to south-west.
The north is affected by pronounced summer rainfall (October to March). In the south precipitation occurs almost the year around.

The knowledge on the Quaternary geology of the ChacoPampa Plain has increased during recent years, mainly due to the implementation of physical dating methods. However, a reasonable and consistent multidisciplinary overview on the morphological and geological development was still missing when SEGEMAR (Servicio Geológico Minero Argentino) assisted by BGR (Federal Institute for Geosciences and Natural Resources, Hannover, Germany) started a geological mapping project in the Chaco-Pampa Plain of the scale of 1:250 000. In the Paraguayan Chaco, the Geological Survey of Germany (BGR) and Paraguayan institutions (e.g. Ministerio de Agricultura) had already performed luminescence and radiocarbon datings within the frame of an environmental mapping program in the 1990s. 


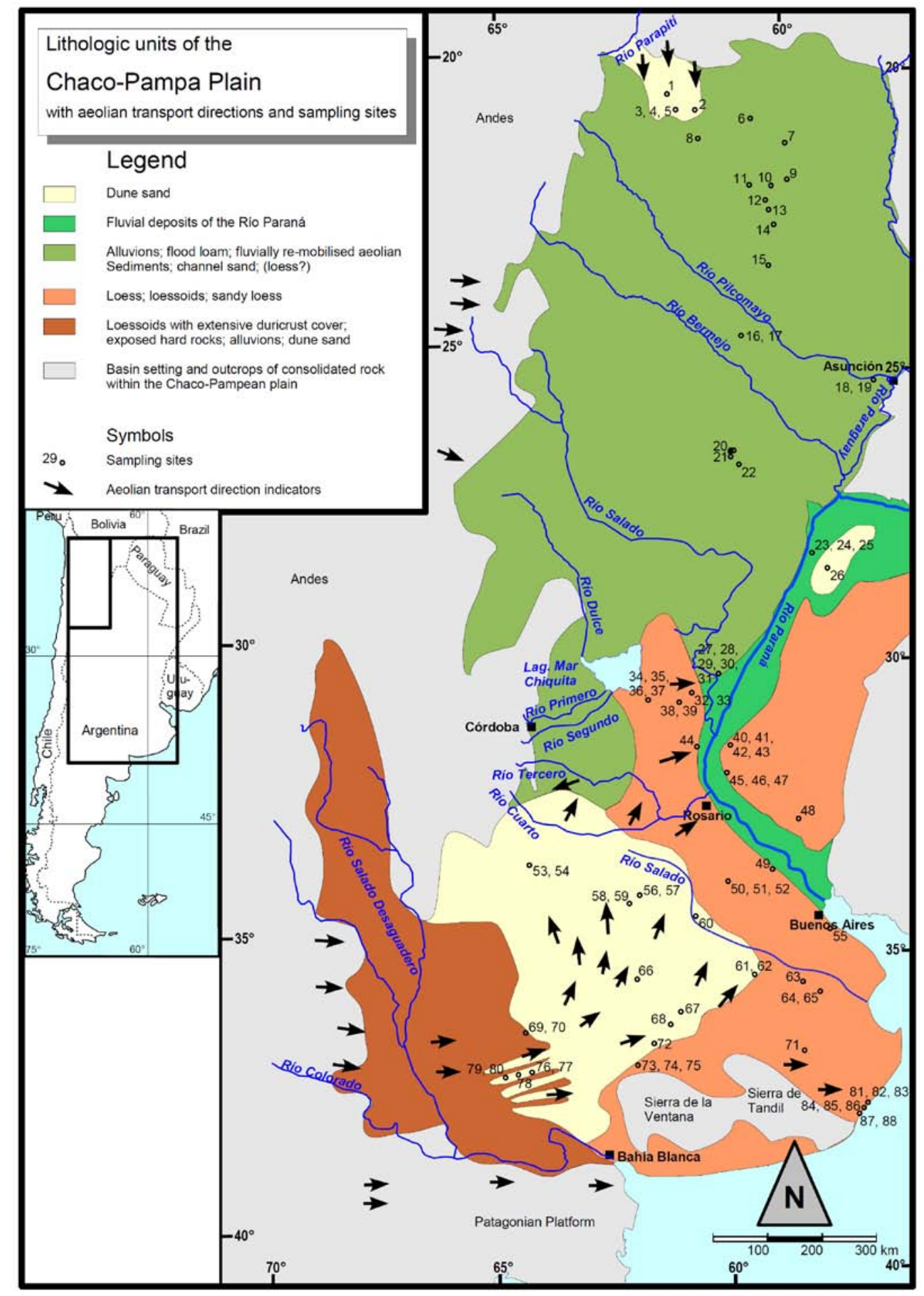

Fig.1: The Chaco-Pampa Plain: Lithology sampling sites and aeolian transport directions. The map was elaborated by means of field observations, satellite image interpretation and information of the cited literature.

Abb. 1: Die Chaco-Pampa Ebene: Lithologie, Probenentnahmepunkte und äolische Transportrichtungen. Die Karte wurde mittels Geländebeobachtungen, Satellitenbildinterpretation und der zitierten Literatur erarbeitet.

\section{Geological, Geomorphological and Climatological Setting}

The Chaco-Pampa Plain is the southern part of the vast South American deposition trough. It extends from the Venezuelan plains in the north to the Río de la Plata Region in the south. The subsidence of this trough, located between the Andean chains and the Brazilian Shield, is related to the opening of the Atlantic and the up-folding of the Andes mountains.

The present topography of the Chaco-Pampa Plain was formed along general lines by the last regression of the Miocene Paranaense Sea. A new basin developed which succes- sively filled with terrestrial sediments. In the south-western Pampa loessoid sediments built up an elevated peneplain dissected by erosion. The sediments are composed of silt and sand with embedded duricrust layers, siliceous/calcareous concretions and nodules. These sequences are palaeontologically assigned to the Upper Miocene (MELChOR et al., 2000; ABELlo et al., 2002) and named Formación Cerro Azul.

In a great part of the Chaco-Pampa Plain Quaternary loess and loessoid deposits cover Pliocene fluvial sand. In present coastal areas marine deposits of the Pleistocene and Holocene ingressions intercalate the dominant terrestrial Quaternary sediments of the Argentine Pampa (Fig. 1).

Teruggi (1957) links the loess in the Pampa to the vol- 
canism of the southern Andes, as it contains 20-60\% of volcanic material. During volcanic eruptions the majority of ash was deposited on the foot of the volcanoes. From here the ashes were repeatedly deflated or fluvially removed (INBAR \& RISSO, 2000) and re-deposited further to the east in great fans. The volcanic activity is still going on. Ashes of the Quizapú eruption on 1932 reached Río de Janeiro (KITTL, 1933). This volcano belongs to the Descabezado Group situated on Chilean territory.

Meanwhile there is general agreement that the main source areas of the loess, loessoid sediments and sands of the Argentine Pampa are from the southwest of the Chaco-Pampa Plain, the flood plains of northern Patagonia and the piedmont of the Andes. Rivers transported material to the south and east, while southerly winds transported it to the north during dry and cold periods of the Pleistocene (e.g. IrIONDO, 1990a; ZÁrATE \& BLASI, 1990). The wide SW-NE directed fan of loessoid deposits is covered by sand dunes in the southwest.

In the northern Chaco-Pampa Plain (northern part of Argentina and western part of Paraguay) the source area of aeolian and fluvial loessoid sediments are the Andine sierras in Argentina and Bolivia. The rivers (e.g. Río Pilcomayo, Río Bermejo, Río Salado) descend from there and flow to the east. They have developed extensive alluvial fans of several hundred kilometres width which are easily visible on satellite imagery. IRIONDO (1990a) and SAYAGO (1995) have a deviating opinion on the proportions of alluvial and pristine loess in the sediments of the river fans. A comprehensive review about the associated problems arising from the distinction of pristine, reworked and fluvial dislocated loess is given by ZÁRATE (2003).

In order to develop a regional lithostratigraphic concept of the Chaco-Pampa Plain numerous local studies were carried out. Formations were defined on the correlation of a small number of representative sites. But the result has still to be improved in order to sharpen the litho- and biostratigraphic as well as geochronologic statements.

The terrestrial Quaternary deposits are famous for their extraordinary richness of fossils at particular sites, which have been investigated very intensively since the $19^{\text {th }}$ century. Ameghino (1908) established an evolutionary succession of the fauna which geologists have tried to correlate without success with lithostratigraphic sequences. Frengueldi (1957) tried to develop a lithostratigraphic sequence of the Pampa sediments by correlating alternating loess and loam sequences with the palaeoclimate of the northern hemisphere. He also failed, causing stratigraphic confusion. The inherent problems were seemingly solved by PASCUAL et al. (1965), who introduced the Edades Mamifero (mammal ages) without taking into account the geological conditions. Therefore, their investigations have not resulted in a clearly defined biostratigraphy. FIDALGO et al. (1975), TonNI et al. (1999) and others differentiate the Pleistocene loess (so-called Pampeano) into two units. The lower unit (Formación Ensenada - Ensenadense) consists of consolidated sediments. The upper unit contains less consolidated loess (Formación Buenos Aires-Bonaerense) and is intercalated by lacustrine and fluvial deposits (Formación Lujan-Lujanense). It is partly covered by Holocene aeolian, lacustrine, fluvial and near the coast by marine sediments. TonNI et al. (1999) differentiate the upper lithological unit in more detail using faunal elements and several radiocarbon dates. But the implementation of physical dating methods also did not overcome the lithostratigraphic problems. Due to the limited dating range of the ${ }^{14} \mathrm{C}$ method only minimum ages of the Pampeano sediments were obtained.

Based on locally restricted geochronological and geological information IRIONDO (1999) developed an ambiguous and regionally questionable palaeoclimatic and palaeogeographic concept selectively adapted to the Marine Isotopic Stage (MIS) chronology of the northern hemisphere. The interpretation problems arising from too small or unreliable data base are demonstrated by PRIETO (1996; 1997) criticizing the regional Holocene chronology by Iriondo (IrIONDO, 1997). IRIONDO (1999) and KröHLING (1999) assume wet and dry (or at least generally semiarid) climate for the periods between ca. $8500 \mathrm{yr}$ cal BP and $3500 \mathrm{cal} \mathrm{BP}$ as well as between $3500 \mathrm{yr}$ cal BP and $1000 \mathrm{yr}$ cal BP, respectively. In opposite GEYH et al. (1996), BARBOZA et al. (2000) and ZECH et al. (2008) provide evidence for dry and wet climate for the succeeding periods. After the predominantly dry mid-Holocene the climate changed to wet about 3500 yr cal BP with several short dry interruptions.

Palaeomagnetic studies in the eighties by e.g. Valencio and Orgeira (1983), Orgeira (1987), Bidegain (1991) and NABEL (1993) detected the Matuyama-Brunhes boundary in the upper part of the Formación Ensenada. This means that the Formación Buenos Aires must be considerably younger than 0.79 Ma. KRÖHLING (1999) and KRÖHLING and IRIONDo (1999) published a small number of luminescence ages which was not sufficient to derive a reliable regional conception of the huge study area. FreCHEN et al. (2009) evaluated the data set of KRöHLING (1999) and conclude that these reported TL age estimates should not be considered for further chronostratigraphic interpretation owing to the lack of methodological background information.

Kemp et al. (2006) describe the large variability of the micromorphological composition of loess and loess-like sediments. Arguello et al. (2010) demonstrate the dominance of loess-like sediments in one profile east of Córdoba which were transported and re-deposited by fluvial processes. As loess is usually diagenetically modified and dune sands are often re-deposited; then luminescence dates represent minimum ages of the associated morphological processes. Due to this situation many previous chronological classifications are misleading.

\section{Material and Methods}

The main lithostratigraphical and geomorphological problems of the previous studies arose from the uniformity of the sediments and the flatness of the huge study area with a few outcrops. This situation hampered the collection of samples suitable for luminescence dating. Luminescence dates are exaggerated if the samples were not completely bleached. Examples might be fluvial remobilized material.

In order to overcome these constrains we had to search for geoscientific methods which allow to join local multi-disciplinary information to a reliable regional geomorphological conception of global relevance. The most suitable method for this task has been found to be satellite remote sensing. 


\subsection{Remote sensing and sedimentological methods}

Remote sensing techniques facilitated the identification of geomorphological and genetically comparable units over long distances. Due to the generous NASA information policy, most of the used satellite material could be obtained free of charge.

Samples of the following systems were downloaded and processed:

- Landsat 5 TM and Landsat 7 ETM+: These systems became the principal source of spectral data.

- SRTM (on Space Shuttle): The only available radar instrument which covered the entire investigated terrain delivered data which allowed an easy pre-processing for the Digital Elevation Model (DEM). The ground resolution is roughly comparable with that of the Landsat imagery. The altitude and spectral information could be evaluated.

- NOAA AVHRR: Its resolution allowed to localize the direction of aeolian sediment transport and deposition areas.

- After downloading the metadata and the single spectral band files in GeoTiff format, each file with single band information was processed as follows:

Uncompressing and visualizing the data by bitmap processing software (GIMP 2.2 and COREL Photo Paint 11).

- Greyscale stretching the histogram without loss of information on the black/white side for contrast optimising (possible only for images without water, cloud cover or snow surfaces).

- Gradation curve adaptation for features on snow-free ground by compressing near the black and/or the white ends without loss of the grey tones.

The satellite image interpretation was important to reconstruct the palaeogeographic situation and deposition processes in the study area. Finally we ended up in a consistent and reasonable regional conception which was verified and refined by means of field studies. Key sites as coincidentally encountered outcrops at road cuts, river banks and excavations in the Argentine Chaco-Pampa Plain were localized for the collection of samples for luminescent dating.

Different types of involved diagenetic processes and the morphological conditions at the sampling sites allowed distinguishing sediments according to aeolian and/or fluvial transport, weathering, and remobilization. This classification was supported by grain size analysis.

\subsection{Luminescence dating of sediments}

Samples for luminescence dating (75 IRSL = infrared stimulated luminescence and $12 \mathrm{TL}=$ thermoluminescence) were taken in the Pampa and the Chaco (Fig. 1). In the Paraguayan Chaco outcrops are so rare that in most cases small holes had to be excavated. The maximum and minimum sampling depth was between 7 and $>0.3 \mathrm{~m}$, the latter due to the requirements of luminescence dating. The luminescence ages and the relevant field and laboratory results are compiled in the Table 1 and 2, respectively. The luminescent ages are given in ka before present.

Samples for luminescence dating were collected between 1993 and 2006 during which luminescence dating techniques made considerable methodical progress (e.g. PrEusser et al., 2008; Wintle, 2008). We applied the meanwhile antiquated dating techniques of the 1990s similar as it was done in almost all previous studies in the Chaco-Pampa Plain. The obtained luminescence dates and their confidence intervals may up to $30 \%$ older than the actual dates but are considered as sufficient reliable for the development of a raw synchronopsis. Three laboratories were involved.

The generalized procedure of collection, treatment and measurement of samples is given as follows: Each sample was taken in a light-tight cylinder from freshly exposed surfaces. The surface layer of the light-exposed part was removed under subdued red-light in the laboratories. Carbonate was removed by diluted hydrochloric acid before various grain-size and mineral fractions were separated by sieving. The 4-11 $\mu \mathrm{m}$ polymineral grain-size fraction was enriched according to Frechen et al. (1996). After this the fractions were treated with sodium oxalate solution and $30 \%$ hydrogen peroxide to remove clay coatings and organic matter. In case of luminescence dating of mono-mineral fractions potassium feldspar and quartz were separated from each other by heavy liquids, such as sodium polytungstate $\left(2.58,2.62\right.$ and $\left.2.70 \mathrm{~g} / \mathrm{cm}^{3}\right)$.

Between 1993-1996 IRSL and TL datings were carried out by the Archaeometry Research Group Heidelberg at the Max-Planck Institute of Nuclear Physics in Heidelberg (P. Kuhn). Polymineral fractions of 4-11 $\mu \mathrm{m}$ size and 100-200 $\mu \mathrm{m}$ quartz extracts were used. Details of the applied technique are given by KuHN (2000).

Between 1999-2000 IRSL, GRSL (green light stimulated luminescence), and TL age determinations were performed at the Geological Institute of the University Cologne (F. Preusser). The 4-11 $\mu \mathrm{m}$ sized polymineral fraction and various coarse grain-size fractions between 63 and $200 \mu \mathrm{m}$ of K-rich feldspars were used. For maintaining consistency only IRSL and TL ages were included in the interpretation though in several cases other kinds of luminescence ages were determined. This was justified because the corresponding ages agreed within a few millennia. Due to methodical reasons - higher probability for insufficient bleaching prior to deposition - exceptional TL ages overestimated the true sedimentation age. The reason is that TL traps require a longer light exposure time for total bleaching of the luminescence signal than luminescence traps (Godfrey-SMITH et al., 1988). Details of his procedure are given by Fuller et al. (1994) and Preusser (1999).

Between 2001 and 2006 the Leibniz Institute for Applied Geosciences in Hannover carried out IRSL age determinations on 4-11 $\mu \mathrm{m}$ sized polymineral fractions and quartz extracts from loess, loessoids and dune sands. The sample preparation and measurement techniques of sands are described by FRECHEN et al. (2001) and of loess by FRECHEN et al. (2009). As the preparation and measurement techniques of the three involved laboratories differ only slightly it seemed to be justified that the reliability of the IRSL and TL ages within the investigated age range of maximum $60 \mathrm{ka}$ is similar.

The multiple-aliquot regeneration and (total bleach) additive dose protocols were applied. The luminescence signal of K-feldspar samples was normalized by short shine measurements. At least six aliquots of the extracts were fixed on aluminium or stainless steel discs and irradiated at least 8-times with stepwise increasing doses using a calibrated ${ }^{90} \mathrm{Sr} /{ }^{90} \mathrm{Y}$ 
beta source for mono-mineral extracts and calibrated ${ }^{60} \mathrm{Co}$ gamma sources for polymineral extracts. After the artificial irradiation, the samples were stored at room temperature for at least four weeks or at $70^{\circ} \mathrm{C}$ for one week. These experiments did not indicate anomalous fading after a delay of 4 weeks to 12 months after artificial irradiation. Several aliquots were exposed to a solar simulator lamp (dr hoenle Sol2) for several hours in order to determine the residual IRSL and TL signal.

The luminescence measurements were started with a subsequent pre-heating of the fine-grained aliquots at less than $200^{\circ} \mathrm{C}$ for at least 15 hours and of the feldspars fraction at more than $200^{\circ} \mathrm{C}$ for at least 1 minute in order to eliminate the unstable component induced by the artificial irradiation. The IRSL and TL signals were measured in commercial TL/OSL readers. Optical filter sets were placed between the sample and the photomultipliers in order to select the blue wavelength spectra for both IRSL and TL measurements. During 25-60 s exposure by IR diodes $(880 \pm 80 \mathrm{~nm})$ the decay curve was recorded. The equivalent dose was integrated from the $10-25$ s section.

From fine grains also TL ages were determined. The TL dose response curve was recorded at a heating rate of $5{ }^{\circ} \mathrm{C} / \mathrm{s}$ applied to $450^{\circ} \mathrm{C}$. Second glow normalization was used to reduce the disc-to-disc scatter of the results. The $300-400^{\circ} \mathrm{C}$ region of the TL dose response curve yielded the equivalent dose. The TL signals of the stepwise irradiated samples were mathematically fitted to an exponential curve and extrapolated to the zero dose which yielded the equivalent dose of the natural luminescence signal.

Dose rates for all samples were calculated from the potassium concentration determined by AAS and the specific activities of potassium, uranium and thorium measured by gamma spectrometry (Table 2). The natural water content of the sediment was assumed to be in the range of $15-35 \pm 5 \%$ in relation to the porosity of the sediment.

\section{Results}

Based on the results of geological field studies, sedimentological investigations and age determinations as well as morphological evaluations using satellite imagery a reconnaissance map was elaborated. It gives a general overview about the lithology, the main aeolian transport directions of sediments and the locality of the sampling sites (Fig.1).

\section{Loess}

We define the loess of the study area as non-stratified, loose and friable, yellowish brown and never dislocated windblown sediment with a grain size composition of predominantly coarse silt and a varying content of fine material (mainly due to weathering). Diagenetic changes do not affect this classification. A specific property of the loess in the Pampean Formation is its abundant volcanic components according to TERUGGI (1957).

Teruggi (1957) and ZÁrAte (2003) found that most sediments previously classified as loess of the Argentine Pampa had a strongly deviating grain size distribution. Our grain size analyses carried out in connection with OSL age determinations confirmed this statement. However, we found 10 sites with pristine loess in the Chaco-Pampa Plain. The grain size of the loess ranges from coarse silt to fine sand. Some clay is also present due to weathering of feldspars. Most loess samples yielded ages between $60 \mathrm{ka}$ and $18 \mathrm{ka}$, two samples exceed these ages.

\section{Loessoids}

Loess dislocated by water or any other loess-like sediment with the appearance of loess independent of its origin are classified as loessoid. Material dislocated by water may yield overestimated luminescence ages due to incomplete bleaching.

The loessoid sediments of the Upper Miocene (Formación Cerro Azul) in the southwest are composed of silt and sand with embedded duricrust layers, siliceous/calcareous concretions and nodules (Grl. Acha, Nos. 76 and 77). A sample of a duricrust covering these sediments yielded a calibrated ${ }^{14} \mathrm{C}$ age of 25,800-24,500 cal BP (Hv 23 838). The actual age might be considerably older, as the samples might had been contaminated with secondary carbonates formed by repeated wetting and weathering

The facial similarity between this poorly sorted material of loessoid deposits in the east is obvious, where samples were taken at the slopes of elongated flat depressions. The samples consisted of silt $(0.004-0.060 \mathrm{~mm})$ and middle sand $(0.20-0.63 \mathrm{~mm})$. They often contained a large amount of clay, which is ascribed to weathering or a result of slope wash. The material is poorly sorted. Due to the topographic situation these sediments were transported only over short distances. OSL ages of 14 samples ranged from $60 \mathrm{ka}$ to $6 \mathrm{ka}$ and those of 9 samples from $32 \mathrm{ka}$ to $18 \mathrm{ka}$. Five samples were older than $60 \mathrm{ka}$.

\section{Dune sand}

In the southern dune field (Pampean Sand Sea - PSS) 16 samples of dune sand were taken. They consisted of well-sorted fine to middle sand. The sites are distributed over the whole study area (Fig.1). Samples of the basal deposits which rest on loessoid sediments were taken along the western rim of the Pampean Sand Sea. At the eastern rim of the Pampean Sand Sea, sampling was done less than 2 meters above the base estimated from the topographic situation. Recent and old sands were found at the eastern and northern rim of the Pampean Sand Sea. The oldest determined OSL ages of sands are minimum ages in case the base of the outcrop was not the base of the sands. Older sands from the dune field northwest of the PSS with OSL ages of $33 \mathrm{ka}$ to $23 \mathrm{ka}$ are described by TRIPALDI \& FORMAN (2007). The thickness of the dune sand sequence is differing with maximum values estimated to about 20 to $30 \mathrm{~m}$.

Five samples were dated from the northern dune field in the Paraguayan Chaco. They were collected between the central and south-eastern part. By topographic calculations their position is less than 3 meters above the dune basis. These sediments have mid-Holocene ages between $5 \mathrm{ka}$ and $3 \mathrm{ka}$. One sample from another dune field located in the east of the Río Paraná is of modern age.

\section{Channel sand}

Satellite images of the northern part of the study area show a pattern of fluvial activity. The related field study confirmed that the corresponding sediments are channel sands from palaeorivers of the Río Pilcomayo-Bermejo-Salado 
system (see also Section 5.2). They are very well sorted with grain sizes between silt and middle sand. Dating of 11 samples yielded OSL ages ranging from $12 \mathrm{ka}$ to $3 \mathrm{ka}$ which may be minimum ages, as the samples had to be collected above the unknown base of these deposits.

\section{Fluvio-lacustrine sediments}

The sampling sites are located near the still active water courses in the back water and flood plain areas. The sediments occur in lenses of clayey diamictit. They have a bimodal grain size distribution from fine to middle sands and clay to fine silt. Several samples contained a high proportion of clay. Two fluvio-lacustrine sediment samples (Nos. 24 and 25) with many fossils were taken from an outcrop at Bella Vista. They yielded OSL ages of $53 \mathrm{ka}$ and $37 \mathrm{ka}$, respectively. These deposits belong palaeontologically to the Formación Toropí and Formación Yupoi (Tonni et al., 2005). At the Arroyo Barrenechea near Diamante, Entre Rios (No. 47) the sediments have an OSL age of $34 \mathrm{ka}$. They contain well preserved fossils, indicating a short transport distance and could belong to the Formación Arroyo Feliciano (IRIONDo et al., 1985). According to the dates both the Formación Yupoi and Formación Arroyo Feliciano would be coeval. Luminescence dates of fluvio-lacustrine sediments obtained by the antiquated technique of 1990s might be exaggerated due to incomplete bleaching.

\section{Flood loam}

On satellite images of the northern Chaco-Pampa Plain macro and dense micro flow patterns are visible. The sediments are badly sorted and the grain sizes ranged from clay $(<0.005 \mathrm{~mm})$ to middle sand. One sample out of nine was older than $60 \mathrm{ka}$, the others were between $30 \mathrm{ka}$ and $2 \mathrm{ka}$ old. Similar to fluvio-lacustrine sediments luminescence ages of flood loam might also be exaggerated due to incomplete bleaching.

\section{Not classified material}

Sediments of unsorted grains and without any clear morphological relationship could not be classified. It is unknown whether they were weathered, bioturbated or fluvial re-mobilized loess. One sand sample taken near Bella Vista might have been of fluvial or aeolian origin. At Mar del Plata sandy sediments underlying marine deposits could have been shore or aeolian sands.

\section{Origin and Fate of the Sediments}

Satellite data evaluation provided evidence that westerly winds dominated in the Argentine Pampa during the Pleistocene. Indications are morphological stripes and furrows in the sedimentary and volcanic cover at the Andean foot-

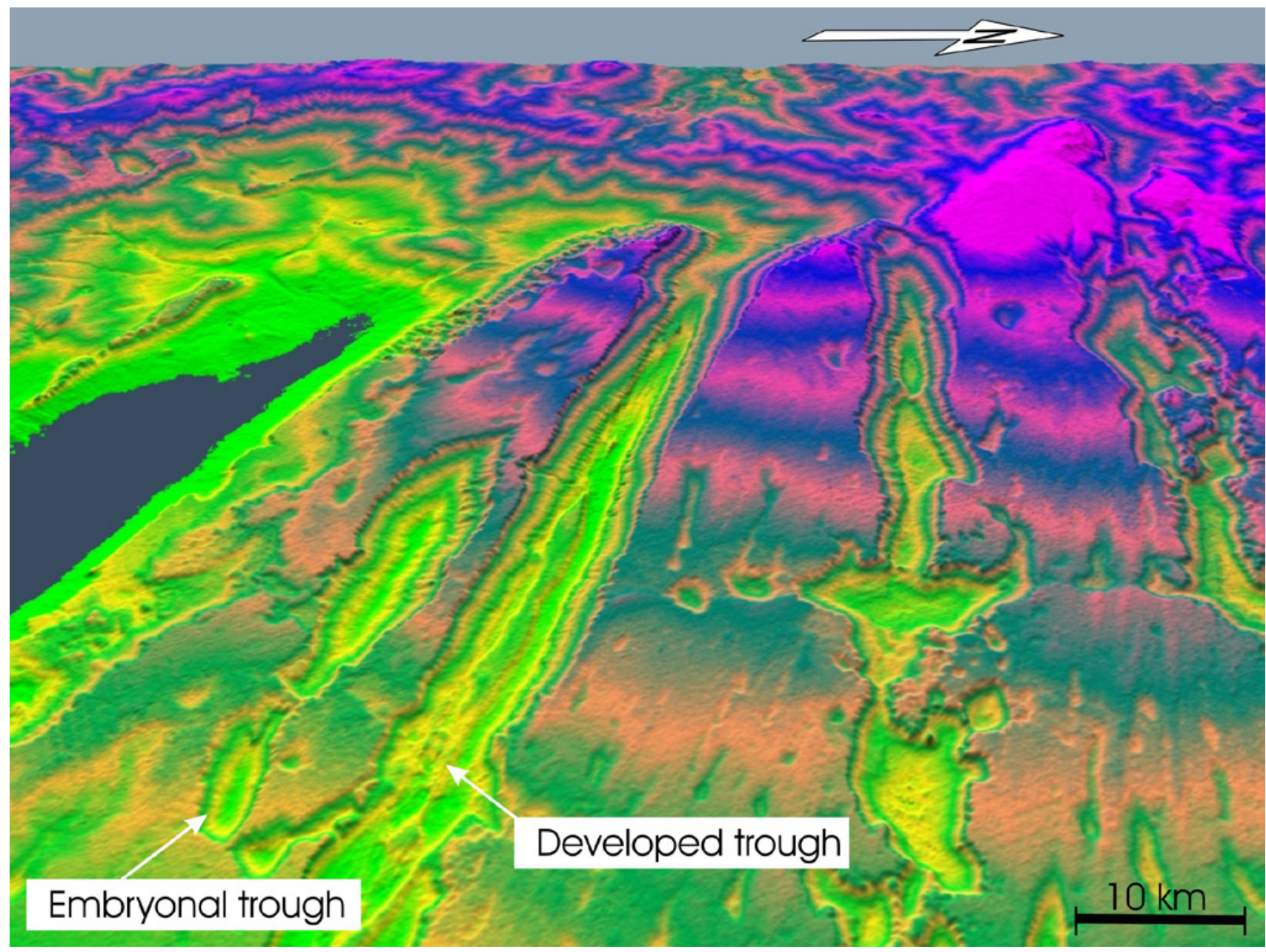

Fig. 2: Digital Elevation Model of the "Valles Grandes" area in the southwestern Pampa (see Fig.1), derived from SRTM data (SRTM tiles: 36S/64W to $39 S / 67$ W). Big and small troughs reflect different stages of aeolian valley evolution. Wind direction was to the east.

Abb. 2: Digitales Höhenmodell vom Gebiet der Valles Grandes in der südwestlichen Pampa (siehe Fig.1), erstellt aus SRTM Daten (SRTM tiles: 36S/64W to 39S/67W). Große und kleine Tröge stellen verschiedene Stadien der äolischen Talbildung dar. Der Wind kam aus dem Westen. 
Tab. 1: Luminescence dates of sediments from the Chaco-Pampa Plain: site description, numerical dates with reference and climatic classification of the samples (Fig. 1 - sample numbers increase from $N$ to $S$ ). Laboratory results of the luminescence dating are compiled in Table 2.

Tab. 1: Lumineszenz-Alter von Sedimenten aus dem Chaco und der Pampa: Angaben zu den Beprobungsorten und klimatische Klassifikation der Proben (Fig. 1 - die Probennummern steigen von S nach N). Laborergebnisse der Lumineszenzdatierung sind in Table 2 zusammengestellt

\begin{tabular}{|c|c|c|c|c|c|c|c|c|c|c|c|}
\hline No. & material & location & $\begin{array}{c}\text { depth } \\
\text { m }\end{array}$ & latitude S & longitude W & method & lab. & \multicolumn{3}{|c|}{$\begin{array}{c}\text { age } \\
\text { ka BP }\end{array}$} & $\begin{array}{c}\text { climatic } \\
\text { classification }\end{array}$ \\
\hline \multicolumn{12}{|c|}{ Samples representing arid climate } \\
\hline 1 & dune sand & Est. Calvet & 1.00 & $20.6545^{\circ}$ & $61.9929^{\circ}$ & $\mathrm{TL}$ & MPI KH & 3.0 & \pm & 0.4 & arid \\
\hline 2 & dune sand & Tte. Enciso/Transchaco & 0.50 & $20.9074^{\circ}$ & $61.5059^{\circ}$ & $\mathrm{TL}$ & MPI K H & 2.9 & \pm & 0.4 & arid \\
\hline 3 & dune sand & Tte. Enciso/Transchaco & 0.45 & $20.9017^{\circ}$ & $61.8443^{\circ}$ & $\mathrm{TL}$ & MPI K H & 3.1 & \pm & 0.5 & arid \\
\hline 4 & dune sand & Tte. Enciso/Transchaco & 0.65 & $20.9017^{\circ}$ & $61.8443^{\circ}$ & $\mathrm{TL}$ & MPI K H & 5.5 & \pm & 0.6 & arid \\
\hline 5 & dune sand & Tte. Enciso/Transchaco & 0.75 & $20.9017^{\circ}$ & $61.8443^{\circ}$ & $\mathrm{TL}$ & MPI K H & 4.8 & \pm & 0.6 & arid \\
\hline 26 & dune sand & 9 de Julio & 1.40 & $28.8369^{\circ}$ & $58.8437^{\circ}$ & IRSL & LIAG & \multicolumn{3}{|c|}{ modern } & arid \\
\hline 27 & loessoid & Autodromo Emilia & 4.65 & $31.0501^{\circ}$ & $60.8176^{\circ}$ & IRSL & LIAG & 96.5 & \pm & 5.6 & arid [?] \\
\hline 28 & loessoid & Autodromo Emilia & 5.10 & $31.0501^{\circ}$ & $60.8176^{\circ}$ & IRSL & LIAG & 91.6 & \pm & 7.6 & arid [?] \\
\hline 29 & loessoid & Autodromo Emilia & 4.00 & $31.0501^{\circ}$ & $60.8176^{\circ}$ & IRSL & LIAG & 84.9 & \pm & 6.7 & arid [?] \\
\hline 34 & loessoid & Freyre & 3.50 & $31.1743^{\circ}$ & $61.9812^{\circ}$ & IRSL & LIAG & 32.1 & \pm & 2.7 & arid [?] \\
\hline 35 & loessoid & Freyre & 2.20 & $31.1743^{\circ}$ & $61.9812^{\circ}$ & IRSL & LIAG & 18.6 & \pm & 1.6 & arid [?] \\
\hline 36 & loessoid & Freyre & 1.85 & $31.1743^{\circ}$ & $61.9812^{\circ}$ & IRSL & LIAG & 17.4 & \pm & 1.5 & arid [?] \\
\hline 37 & loessoid & \begin{tabular}{|l|} 
Freyre \\
\end{tabular} & 0.90 & $31.1743^{\circ}$ & $61.9812^{\circ}$ & IRSL & LIAG & 5.8 & \pm & 0.6 & arid [?] \\
\hline 38 & loessoid & \begin{tabular}{|l|} 
Rafaela \\
\end{tabular} & 1.30 & $31.2362^{\circ}$ & $61.4508^{\circ}$ & IRSL & Uni Cologne & 28.8 & \pm & 2.9 & arid [?] \\
\hline 39 & loessoid & Rafaela & 2.50 & $31.2362^{\circ}$ & $61.4508^{\circ}$ & IRSL & Uni Cologne & 18.8 & \pm & 3.2 & arid [?] \\
\hline 40 & loessoid & Parana & 2.55 & $31.7031^{\circ}$ & $60.4769^{\circ}$ & IRSL & LIAG & 56.6 & \pm & 5 & arid [?] \\
\hline 41 & loessoid & Paraná & 0.65 & $31.7031^{\circ}$ & $60.4769^{\circ}$ & IRSL & LIAG & 28.3 & \pm & 2.4 & arid [?] \\
\hline 42 & loessoid & Paraná & 1.40 & $31.7031^{\circ}$ & $60.4769^{\circ}$ & IRSL & LIAG & 26.9 & \pm & 2.3 & arid [?] \\
\hline 43 & loessoid & Paraná & 2.65 & $31.7031^{\circ}$ & $60.4769^{\circ}$ & IRSL & LIAG & 23.2 & \pm & 1.8 & arid [?] \\
\hline 46 & loess & Diamante & 1.90 & $32.0665^{\circ}$ & $60.6242^{\circ}$ & IRSL & LIAG & 17.8 & \pm & 1.3 & arid \\
\hline 49 & loessoid & Autodromo Barradero & 2.30 & $33.8206^{\circ}$ & $59.4778^{\circ}$ & IRSL & Uni Cologne & 40.2 & \pm & 6.3 & arid [?] \\
\hline 52 & loess & Arrecifes & 0.40 & $34.0644^{\circ}$ & $60.0616^{\circ}$ & IRSL & LIAG & 26.9 & \pm & 1.9 & arid \\
\hline 53 & dune sand & Vicuña Mackenna & 3.15 & $33.9303^{\circ}$ & $64.3724^{\circ}$ & IRSL & Uni Cologne & 12.4 & \pm & 1.0 & arid \\
\hline 54 & dune sand & Vicuña Mackenna & 1.35 & $33.9303^{\circ}$ & $64.3724^{\circ}$ & IRSL & Uni Cologne & 2.9 & \pm & 0.5 & arid \\
\hline 56 & loess & La Picasa N & 1.30 & $34.3856^{\circ}$ & $62.2118^{\circ}$ & GSA & LIAG & \multicolumn{3}{|c|}{$144 \pm 16$} & arid \\
\hline 57 & dune sand & La Picasa N & 0.40 & $34.3856^{\circ}$ & $62.2118^{\circ}$ & IRSL & LIAG & 16.1 & \pm & 1.2 & arid \\
\hline 58 & loess & La Picasa S & 1.50 & $34.4557^{\circ}$ & $62.3776^{\circ}$ & IRSL & LIAG & 26.4 & \pm & 1.9 & arid \\
\hline 59 & dune sand & La Picasa S & 0.60 & $34.4557^{\circ}$ & $62.3776^{\circ}$ & IRSL & LIAG & 10.9 & \pm & 1.3 & arid \\
\hline 60 & dune sand & Junin & 1.50 & $34.6614^{\circ}$ & $60.9861^{\circ}$ & IRSL & Uni Cologne & 7.3 & \pm & 1.4 & arid \\
\hline 61 & dune sand & Saladillo & 1.40 & $35.5936^{\circ}$ & $59.7431^{\circ}$ & IRSL & LIAG & 14.2 & \pm & 3.2 & arid \\
\hline 62 & dune sand & Saladillo & 0.40 & $35.5936^{\circ}$ & $59.7431^{\circ}$ & IRSL & LIAG & \multicolumn{3}{|c|}{ modern } & arid \\
\hline 63 & dune sand & San Miguel del Monte & 0.70 & $35.6602^{\circ}$ & $58.8016^{\circ}$ & IRSL & Uni Cologne & 9.8 & \pm & 1.2 & arid \\
\hline 64 & loess & Grl. Belgrano & 1.50 & $35.8301^{\circ}$ & $58.4082^{\circ}$ & IRSL & Uni Cologne & 57.8 & \pm & 7.6 & arid \\
\hline 65 & loess & Grl. Belgrano & 1.20 & $35.8301^{\circ}$ & $58.4082^{\circ}$ & IRSL & Uni Cologne & 17.9 & \pm & 3.2 & arid \\
\hline 67 & dune sand & San Carlos de Bolivar & 1.40 & $36.2725^{\circ}$ & $61.2123^{\circ}$ & IRSL & Uni Cologne & 10.6 & \pm & 1.7 & arid \\
\hline 68 & dune sand & Pirovano & 2.50 & $36.5069^{\circ}$ & $61.566^{\circ}$ & IRSL & LIAG & 6.7 & \pm & 1.3 & arid \\
\hline 69 & dune sand & Toay & 5.50 & $36.6835^{\circ}$ & $64.4142^{\circ}$ & IRSL & Uni Cologne & 3.8 & \pm & 0.4 & arid \\
\hline 70 & dune sand & Toay & 3.50 & $36.6835^{\circ}$ & $64.4142^{\circ}$ & IRSL & Uni Cologne & 0.3 & \pm & 0.1 & arid \\
\hline 71 & loess & Arroyo El Perdido & 1.35 & $36.8104^{\circ}$ & $58.5675^{\circ}$ & IRSL & Uni Cologne & 13.1 & \pm & 1.8 & arid \\
\hline 72 & dune sand & Cochiso/Alsina & 1.25 & $36.9138^{\circ}$ & $62.246^{\circ}$ & IRSL & LIAG & 5.0 & \pm & 1.7 & arid \\
\hline 73 & loessoid & Carhue W & 1.24 & $37.2042^{\circ}$ & $62.8621^{\circ}$ & GSA & LIAG & 139 & \pm & 7 & arid [?] \\
\hline 74 & loessoid & Carhue W & 3.15 & $37.2042^{\circ}$ & $62.8621^{\circ}$ & GSA & LIAG & 123 & \pm & 7 & arid [?] \\
\hline 75 & loessoid & Carhue W & 0.85 & $37.2042^{\circ}$ & $62.8621^{\circ}$ & IRSL & LIAG & 21.6 & \pm & 2.2 & arid [?] \\
\hline 78 & dune sand & Grl. Acha N & 2.80 & $37.3633^{\circ}$ & $64.5970^{\circ}$ & IRSL & Uni Cologne & 2.3 & \pm & 0.3 & arid \\
\hline 79 & dune sand & Grl. Acha W & 3.50 & $37.3978^{\circ}$ & $64.8577^{\circ}$ & IRSL & Uni Cologne & 5.4 & \pm & 0.5 & arid \\
\hline 80 & dune sand & Grl. Acha W & 4.50 & $37.3978^{\circ}$ & $64.8577^{\circ}$ & IRSL & Uni Cologne & 5.0 & \pm & 0.6 & arid \\
\hline 82 & loessoid & $\begin{array}{l}\text { Mar del Plata Santa } \\
\text { Clara d.M. }\end{array}$ & 0.50 & $37.8602^{\circ}$ & $57.5082^{\circ}$ & IRSL & LIAG & 55.2 & \pm & 4.4 & arid [?] \\
\hline 85 & loess & Mar del Plata Camet & 1.70 & $37.9084^{\circ}$ & $57.5215^{\circ}$ & GSA & LIAG & 103 & \pm & 140 & arid \\
\hline 86 & loess & Mar del Plata Camet & 0.30 & $37.9084^{\circ}$ & $57.5215^{\circ}$ & IRSL & LIAG & 53.7 & \pm & 3.3 & arid \\
\hline 88 & loess & Mar del Plata & 0.50 & $37.9577^{\circ}$ & $57.534^{\circ}$ & IRSL & LIAG & 45.7 & \pm & 2.9 & arid \\
\hline
\end{tabular}




\begin{tabular}{|c|c|c|c|c|c|c|c|c|c|c|c|}
\hline No. & material & location & $\begin{array}{c}\text { depth } \\
\text { m }\end{array}$ & latitude $\mathbf{S}$ & \begin{tabular}{|c|} 
longitude \\
W
\end{tabular} & method & lab. & age & \multicolumn{2}{|c|}{ ka BP } & $\begin{array}{c}\text { climatic } \\
\text { classification }\end{array}$ \\
\hline \multicolumn{12}{|c|}{ Fluvial samples representing arid climate } \\
\hline 6 & channel sand & Tte. Pico/Est. San Juan & 0.60 & $21.0527^{\circ}$ & $60.5425^{\circ}$ & TL & MPI KH & 3.3 & \pm & 0.4 & arid/palaeoriver \\
\hline 7 & channel sand & Filadelfia/Madrejon & 0.60 & $21.4390^{\circ}$ & $59.8682^{\circ}$ & $\overline{T L}$ & MPI KH & 7.7 & \pm & 0.9 & arid/palaeoriver \\
\hline 10 & channel sand & Campo Aroma & 0.55 & $22.1692^{\circ}$ & $60.0714^{\circ}$ & TL & MPI KH & 4.6 & \pm & 0.6 & arid/palaeoriver \\
\hline 13 & channel sand & Neuland & 0.60 & $22.5699^{\circ}$ & $60.0927^{\circ}$ & TL & MPI K H & 3.4 & \pm & 0.4 & arid/palaeoriver \\
\hline 14 & channel sand & Neuland & 0.60 & $22.8689^{\circ}$ & $60.0205^{\circ}$ & $\mathrm{TL}$ & MPI KH & 4.5 & \pm & 0.7 & arid/palaeoriver \\
\hline 15 & channel sand & Pozo Col./Grl.Diaz & 0.60 & $23.4882^{\circ}$ & $60.0696^{\circ}$ & TL & MPI KH & 6.4 & \pm & 0.9 & arid/palaeoriver \\
\hline 16 & channel sand & Las Lomitas & 3.40 & $24.7416^{\circ}$ & $60.5512^{\circ}$ & IRSL & $\begin{array}{c}\text { Uni } \\
\text { Cologne }\end{array}$ & 12.4 & \pm & 2.2 & arid/palaeoriver \\
\hline 17 & channel sand & Las Lomitas & 2.05 & $24.7416^{\circ}$ & $60.5512^{\circ}$ & IRSL & $\begin{array}{c}\text { Uni } \\
\text { Cologne }\end{array}$ & 11.8 & \pm & 0.8 & arid/palaeoriver \\
\hline 18 & channel sand & Clorinda W & 1.80 & $25.2528^{\circ}$ & $58.0109^{\circ}$ & IRSL & $\begin{array}{c}\text { Uni } \\
\text { Cologne }\end{array}$ & 3.0 & \pm & 0.3 & arid/palaeoriver \\
\hline 19 & channel sand & Clorinda W & 1.60 & $25.2528^{\circ}$ & $58.0109^{\circ}$ & IRSL & $\begin{array}{l}\text { Uni } \\
\text { Cologne }\end{array}$ & 3.0 & \pm & 0.2 & arid/palaeoriver \\
\hline 21 & channel sand & 7km N Napenay & 0.50 & $26.6732^{\circ}$ & $60.6293^{\circ}$ & IRSL & $\begin{array}{l}\text { Uni } \\
\text { Cologne } \\
\end{array}$ & 3.7 & \pm & 0.3 & arid/palaeoriver \\
\hline \multicolumn{12}{|c|}{ Samples representing humid climate } \\
\hline 8 & flood loam & La Patria & 1.00 & $21.4001^{\circ}$ & $61.4374^{\circ}$ & IRSL & MPI KH & 9.8 & \pm & 1.3 & humid \\
\hline 9 & flood loam & Tte. Montania & 0.45 & $22.0523^{\circ}$ & $59.9282^{\circ}$ & IRSL & MPI KH & 2.1 & \pm & 0.2 & humid \\
\hline 11 & flood loam & Transchaco/Lag. Negra & 2.00 & $22.1809^{\circ}$ & $60.4494^{\circ}$ & $\mathrm{TL}$ & MPI KH & 12.3 & \pm & 1.5 & humid \\
\hline 12 & flood loam & Transchaco/Fila. & 1.00 & $22.4370^{\circ}$ & $60.1293^{\circ}$ & IRSL & MPI KH & 12.1 & \pm & 2.6 & humid \\
\hline 20 & flood loam. & 7km N Napenay & 1.20 & $26.6692^{\circ}$ & $60.6287^{\circ}$ & IRSL & $\begin{array}{c}\text { Uni } \\
\text { Cologne } \\
\end{array}$ & 19.8 & \pm & 1.3 & humid \\
\hline 22 & flood loam & Grl. Roque Saenz Peña & 2.75 & $26.7809^{\circ}$ & $60.4781^{\circ}$ & IRSL & $\begin{array}{c}\text { Uni } \\
\text { Cologne } \\
\end{array}$ & 28.7 & \pm & 5.4 & humid \\
\hline 23 & well sorted sand & Bella Vista. Corrientes & 0.50 & $28.5947^{\circ}$ & $59.0430^{\circ}$ & GSA & LIAG & 115 & \pm & 7 & not classified \\
\hline 24 & $\begin{array}{l}\text { fluvio-lacustrine } \\
\text { clayey diamict }\end{array}$ & Bella Vista/ Corrientes & 6.50 & $28.5943^{\circ}$ & $59.0484^{\circ}$ & IRSL & LIAG & 53.2 & \pm & 3.9 & humid \\
\hline 25 & $\begin{array}{l}\text { fluvio-lacustrine } \\
\text { clayey diamict }\end{array}$ & Bella Vista/ Corrientes & 2.00 & $28.5943^{\circ}$ & $59.0484^{\circ}$ & IRSL & LIAG & 36.7 & \pm & 2.2 & humid \\
\hline 27 & flood loam & Autodromo Emilia & 4.65 & $31.0501^{\circ}$ & $60.8176^{\circ}$ & IRSL & LIAG & 96.5 & \pm & 5.6 & humid \\
\hline 30 & flood loam & Autodromo Emilia & 5.05 & $31.0501^{\circ}$ & $60.8176^{\circ}$ & IRSL & LIAG & 46.5 & \pm & 3.2 & humid \\
\hline 31 & flood loam & Autodromo Emilia & 1.80 & $31.0501^{\circ}$ & $60.8176^{\circ}$ & IRSL & LIAG & 25.8 & \pm & 2.2 & humid \\
\hline 32 & loessoid & Felicia & 1.70 & $31.1891^{\circ}$ & $61.2153^{\circ}$ & IRSL & LIAG & 34.6 & \pm & 2.8 & not classified \\
\hline 33 & $\begin{array}{l}\text { fluvio-lacustrine } \\
\text { clayey diamict }\end{array}$ & Felicia & 1.00 & $31.1891^{\circ}$ & $61.2153^{\circ}$ & IRSL & LIAG & 15.8 & \pm & 1.5 & humid \\
\hline 44 & $\begin{array}{l}\text { fluvio-lacustrine } \\
\text { clayey diamict }\end{array}$ & $\begin{array}{l}\text { Arroyo } \\
\text { Colastiné;Gessler }\end{array}$ & 1.00 & $31.9148^{\circ}$ & $61.1204^{\circ}$ & IRSL & LIAG & 14.3 & \pm & 1.5 & humid \\
\hline 45 & clay with silt & $\begin{array}{l}\text { Diamante/Camino al } \\
\text { Balneario Valle María } \\
\end{array}$ & 1.90 & $32.0101^{\circ}$ & $60.6387^{\circ}$ & GSA & LIAG & \multicolumn{3}{|c|}{$\begin{array}{l}\text { not datable } \\
\text { saturation }\end{array}$} & humid [?] \\
\hline 47 & $\begin{array}{l}\text { fluvio-lacustrine } \\
\text { clayey diamict }\end{array}$ & \begin{tabular}{|l} 
Diamante/Arr. \\
Barrenechea \\
\end{tabular} & 1.60 & $32.0729^{\circ}$ & $60.5594^{\circ}$ & IRSL & LIAG & 34.3 & \pm & 2.1 & humid \\
\hline 48 & $\begin{array}{l}\text { fluvio-lacustrine } \\
\text { clayey diamict }\end{array}$ & Larocca & 1.90 & $33.0190^{\circ}$ & $59.0013^{\circ}$ & IRSL & $\begin{array}{c}\text { Uni } \\
\text { Cologne } \\
\end{array}$ & 12.1 & \pm & 1.4 & humid \\
\hline 50 & clayey silt & Arrecifes & 2.20 & $34.0644^{\circ}$ & $60.0616^{\circ}$ & GSA & LIAG & 207 & \pm & 11 & not classified \\
\hline 51 & $\begin{array}{l}\text { fluvio-lacustrine } \\
\text { clayey diamict }\end{array}$ & Arrecifes & 4.65 & $34.0641^{\circ}$ & $60.0610^{\circ}$ & GSA & LIAG & 159 & \pm & 12 & humid \\
\hline 55 & clayey silt & La Plata & 7.00 & $34.9082^{\circ}$ & $58.0111^{\circ}$ & GSA & LIAG & $>390$ & & & not classified \\
\hline 66 & $\begin{array}{l}\text { fluvio-lacustrine } \\
\text { clayey diamict }\end{array}$ & Canal Jauretche & 1.50 & $35.7216^{\circ}$ & $62.0808^{\circ}$ & IRSL & $\begin{array}{c}\text { Uni } \\
\text { Cologne } \\
\end{array}$ & 8.2 & \pm & 0.7 & humid \\
\hline 76 & silty diamict & Grl. Acha E & 3.80 & $37.3478^{\circ}$ & $64.2887^{\circ}$ & GSA & $\begin{array}{c}\text { Uni } \\
\text { Cologne } \\
\end{array}$ & \multicolumn{3}{|c|}{ not datable } & humid [?] \\
\hline 77 & silty diamict & Grl. Acha E & 2.40 & $37.3478^{\circ}$ & $64.2887^{\circ}$ & GSA & $\begin{array}{c}\text { Uni } \\
\text { Cologne } \\
\end{array}$ & \multicolumn{3}{|c|}{ not datable } & humid [?] \\
\hline 81 & $\begin{array}{l}\text { sand [shore } \\
\text { sand?] }\end{array}$ & $\begin{array}{l}\text { Mar del Plata Santa } \\
\text { Clara d.M. } \\
\end{array}$ & 6.10 & $37.8602^{\circ}$ & $57.5082^{\circ}$ & GSA & LIAG & 104 & \pm & 6 & not classified \\
\hline 83 & $\begin{array}{l}\text { fluvio-lacustrine } \\
\text { clayey diamict }\end{array}$ & $\begin{array}{l}\text { Mar del Plata Santa } \\
\text { Clara d.M. } \\
\end{array}$ & 1.60 & $37.8602^{\circ}$ & $57.5082^{\circ}$ & IRSL & LIAG & 53.8 & \pm & 5.2 & humid \\
\hline 84 & \begin{tabular}{|l|} 
fluvio-lacustrine \\
clayey diamict
\end{tabular} & Mar del Plata Camet & 0.50 & $37.9084^{\circ}$ & $57.5215^{\circ}$ & GSA & LIAG & 121 & \pm & 6 & humid \\
\hline 87 & clayey silt & Mar del Plata & 1.80 & $37.9577^{\circ}$ & $57.5340^{\circ}$ & GSA & LIAG & & & & not classified \\
\hline
\end{tabular}

Abbreviations: lab - laboratory: UNI Cologne - University of Cologne (F. Preusser); LIAG - Leibniz Institute of Applied Geophysics, Hannover (M. Frechen); MPI K H - Max Planck Institute of Nuclear Physics, Heidelberg (R. Kuhn); method: IRSL - infrared-stimulated luminescence; TL - thermoluminescence; age; GSA - grain size analysis 
Tab. 2: Dated fraction, analytical results, dose rate measurements and estimates, assumed moisture content and equivalent dose of sediments samples from the Chaco-Pampa Plain (see Table1 and Fig. 1 - sample numbers increase from N to S). Analytical data from the Max-Planck-Institute Heidelberg (MPI H) are missing.

Tab. 2: Datierter Sedimentextrakt, analytische Ergebnisse, angenommener Feuchtgehalt, gemessene und geschätzte Dosisraten und Äquivalenzdosis der Proben vom der Pampa und dem Chaco (s. Tabelle 1 und Fig. 1 - die Probenummern steigen von N nach S. Die Laborergebnisse der Lumineszenzalter vom Max-Planck-Institut Heidelberg liegen nicht vor.

\begin{tabular}{|c|c|c|c|c|c|c|c|c|c|}
\hline No. & location & $\begin{array}{c}\text { grain size } \\
\text { mineral }\end{array}$ & $\begin{array}{l}\mathrm{K} \\
\%\end{array}$ & $\begin{array}{c}\text { Th } \\
\text { ppm }\end{array}$ & $\begin{array}{c}\text { U } \\
\text { ppm }\end{array}$ & $\begin{array}{c}\text { water } \\
\%\end{array}$ & $\begin{array}{c}\mathrm{d}_{\operatorname{cosm}} \\
\mathrm{mGy/a}\end{array}$ & $\begin{array}{c}\mathrm{d}_{\text {tot }} \\
\mathrm{mGy} / \mathrm{a}\end{array}$ & $\begin{array}{l}D_{\text {equ }} \\
\text { Gy }\end{array}$ \\
\hline \multicolumn{10}{|c|}{ Samples representing arid climate } \\
\hline 1 & Est. Calvet & 4-11 mm P & & & & & & & \\
\hline 2 & \begin{tabular}{|l|} 
Tte. Enciso/ \\
Transchaco
\end{tabular} & 90-२०० mm Q & & & & & & & \\
\hline 3 & \begin{tabular}{|l|} 
Tte. Enciso/ \\
Transchaco \\
\end{tabular} & 9०-२०० mm Q & & & & & & & \\
\hline 4 & \begin{tabular}{|l|} 
Tte. Enciso/ \\
Transchaco \\
\end{tabular} & 90-200 mm Q & & & & & & & \\
\hline 5 & $\begin{array}{l}\text { Tte. Enciso/ } \\
\text { Transchaco } \\
\end{array}$ & 90-200 mm Q & & & & & & & \\
\hline 26 & 9 de Julio & 4-11 mm P & $1.09 \pm 0.02$ & $4.55 \pm 0061$ & $0.35 \pm 0.02$ & $15 \pm 5$ & $182 \pm 9$ & $4.17 \pm 0.33$ & $133.9 \pm 4.7$ \\
\hline 27 & \begin{tabular}{|l|} 
Autodromo \\
Emilia \\
\end{tabular} & 4-11 mm P & $1.71 \pm 0.08$ & $5.29 \pm 0.26$ & $1.49 \pm 0.07$ & $15 \pm 5$ & $172 \pm 9$ & $2.68 \pm 0.14$ & $258.3 \pm 5.8$ \\
\hline 28 & \begin{tabular}{|l} 
Autodromo \\
Emilia
\end{tabular} & 4-11 mm P & $1.82 \pm 0.09$ & $8.97 \pm 0.54$ & $1.62 \pm 0.10$ & $15 \pm 5$ & $178 \pm 9$ & $3.34 \pm 0.24$ & $305.5 \pm 9.6$ \\
\hline 29 & \begin{tabular}{|l|} 
Autodromo \\
Emilia \\
\end{tabular} & 4-11 mm P & $1.99 \pm 0.10$ & $8.66 \pm 0.52$ & $1.59 \pm 0.19$ & $15 \pm 5$ & $175 \pm 9$ & $3.44 \pm 0.27$ & $291.6 \pm 5.2$ \\
\hline 34 & Freyre & $4-11 \mathrm{~mm} P$ & $2.35 \pm 0.12$ & $10.20 \pm 0.61$ & $2.26 \pm 0.14$ & $15 \pm 5$ & $182 \pm 9$ & $4.17 \pm 0.33$ & $133.9 \pm 4.7$ \\
\hline 35 & Freyre & 4-11 mm P & $2.20 \pm 0.11$ & $9.72 \pm 0.58$ & $2.34 \pm 0.14$ & $15 \pm 5$ & $190 \pm 10$ & $4.03 \pm 0.31$ & $74.9 \pm 2.6$ \\
\hline 36 & Freyre & 4-11 mm P & $2.18 \pm 0.11$ & $10.30 \pm 0.62$ & $2.29 \pm 0.14$ & $15 \pm 5$ & $192 \pm 10$ & $4.06 \pm 0.32$ & $70.4 \pm 2.3$ \\
\hline 37 & Freyre & $4-11$ mm P & $2.37 \pm 0.12$ & $8.75 \pm 0.53$ & $2.21 \pm 0.13$ & $15 \pm 5$ & $197 \pm 10$ & $4.03 \pm 0.31$ & $23.3 \pm 1.4$ \\
\hline 38 & Rafaela & $4-11 \mathrm{~mm} P$ & $1.97 \pm 0.10$ & $10.43 \pm 0.52$ & $2.20 \pm 0.11$ & $20 \pm 5$ & 145 & $3.40 \pm 0.30$ & $97.3 \pm 7.8$ \\
\hline 39 & Rafaela & 4-11 mm P & $1.90 \pm 0.10$ & $10.33 \pm 0.52$ & $2.32 \pm 0.12$ & $20 \pm 5$ & 125 & $3.50 \pm 0.30$ & $66.6 \pm 13.0$ \\
\hline 40 & Parana & 4-11 mm P & $2.89 \pm 0.14$ & $8.98 \pm 0.54$ & $1.51 \pm 0.09$ & $15 \pm 5$ & $209 \pm 10$ & $4.26 \pm 0.32$ & $241.1 \pm 10.7$ \\
\hline 41 & Paraná & 4-11 mm P & $2.28 \pm 0.11$ & $9.86 \pm 0.59$ & $1.77 \pm 0.11$ & $15 \pm 5$ & $207 \pm 10$ & $3.92 \pm 0.30$ & $111.0 \pm 3.6$ \\
\hline 42 & Paraná & 4-11 mm P & $2.57 \pm 0.13$ & $9.48 \pm 0.57$ & $1.61 \pm 0.10$ & $15 \pm 5$ & $201 \pm 10$ & $4.06 \pm 0.31$ & $109.2 \pm 4.2$ \\
\hline 43 & Paraná & $4-11$ mm P & $3.33 \pm 0.17$ & $8.92 \pm 0.54$ & $1.42 \pm 0.09$ & $15 \pm 5$ & $193 \pm 10$ & $4.58 \pm 0.35$ & $106.3 \pm 1.7$ \\
\hline 46 & Diamante & 4-11 mm P & $1.54 \pm 0.04$ & $8.04 \pm 0.40$ & $1.69 \pm 0.09$ & $15 \pm 5$ & $192 \pm 10$ & $3.03 \pm 0.16$ & $54.0 \pm 2.7$ \\
\hline 49 & $\begin{array}{l}\text { Autodromo } \\
\text { Barradero } \\
\end{array}$ & 4-11 mm P & $1.62 \pm 0.08$ & $10.30 \pm 0.51$ & $2.30 \pm 0.12$ & $20 \pm 5$ & 125 & $3.20 \pm 0.20$ & $128.5 \pm 19.0$ \\
\hline 52 & Arrecifes & 4-11 mm P & $1.92 \pm 0.05$ & $4.58 \pm 0.23$ & $1.64 \pm 0.08$ & $15 \pm 5$ & $202 \pm 10$ & $2.98 \pm 0.15$ & $80.0 \pm 4.3$ \\
\hline 53 & \begin{tabular}{|l} 
Vicuña \\
Mackenna \\
\end{tabular} & $\begin{array}{c}100-150 \\
\mathrm{~mm} \mathrm{~F}\end{array}$ & $1.79 \pm 0.09$ & $7.00 \pm 0.35$ & $1.83 \pm 0.09$ & $10 \pm 5$ & 110 & $3.10 \pm 0.20$ & $38.9 \pm 1.9$ \\
\hline 54 & \begin{tabular}{|l|} 
Vicuña \\
Mackenna \\
\end{tabular} & $\begin{array}{c}100-150 \\
\mathrm{~mm} \mathrm{~F}\end{array}$ & $1.71 \pm 0.09$ & $7.11 \pm 0.36$ & $1.90 \pm 0.10$ & $10 \pm 5$ & 145 & $3.10 \pm 0.20$ & $9.0 \pm 1.4$ \\
\hline 56 & La Picasa N & 4-11 mm P & $1.80 \pm 0.09$ & $3.27 \pm 0.17$ & $1.92 \pm 0.10$ & $15 \pm 5$ & $193 \pm 10$ & $2.89 \pm 0.15$ & $416.0 \pm 41.0$ \\
\hline 57 & La Picasa N & 4-11 mm P & $1.90 \pm 0.10$ & $4.03 \pm 0.24$ & $1.91 \pm 0.10$ & $15 \pm 5$ & $206 \pm 10$ & $3.01 \pm 0.16$ & $48.4 \pm 2.3$ \\
\hline 58 & La Picasa S & 4-11 mm P & $2.07 \pm 0.10$ & $9.53 \pm 0.48$ & $1.89 \pm 0.10$ & $15 \pm 5$ & $190 \pm 10$ & $3.73 \pm 0.20$ & $98.5 \pm 4.7$ \\
\hline 59 & La Picasa S & 4-11 mm P & $1.98 \pm 0.08$ & $9.55 \pm 0.48$ & $1.88 \pm 0.09$ & $15 \pm 5$ & $202 \pm 10$ & $3.66 \pm 0.20$ & $40.0 \pm 4.1$ \\
\hline 60 & Junin & 4-11 mm P & $1.82 \pm 0.09$ & $7.02 \pm 0.35$ & $2.01 \pm 0.10$ & $20 \pm 5$ & 145 & $3.00 \pm 0.20$ & $12.45 \pm 0.7$ \\
\hline 61 & Saladillo & $4-11 \mathrm{~mm} P$ & $1.90 \pm 0.05$ & $3.44 \pm 0.17$ & $1.23 \pm 0.06$ & $15 \pm 5$ & $197 \pm 10$ & $2.68 \pm 0.13$ & $37.9 \pm 8.5$ \\
\hline 62 & Saladillo & 4-11 mm P & $1.09 \pm 0.02$ & $4.55 \pm 0.06$ & $0.35 \pm 0.02$ & $15 \pm 5$ & $193 \pm 10$ & 0 & 0 \\
\hline 63 & \begin{tabular}{|l|}
$\begin{array}{l}\text { San Miguel } \\
\text { del Monte }\end{array}$ \\
\end{tabular} & dune sand & $1.81 \pm 0.09$ & $8.36 \pm 0.42$ & $2.09 \pm 0.10$ & $10 \pm 5$ & 145 & $3.40 \pm 0.20$ & $32.7 \pm 3.3$ \\
\hline 64 & Grl. Belgrano & 4-11 mm P & $1.53 \pm 0.08$ & $7.54 \pm 0.38$ & $1.99 \pm 0.10$ & $20 \pm 5$ & 145 & $2.80 \pm 0.20$ & $159.6 \pm 16.4$ \\
\hline 65 & Grl. Belgrano & 4-11 mm P & $1.85 \pm 0.09$ & $8.95 \pm 0.45$ & $1.87 \pm 0.09$ & $20 \pm 5$ & 150 & $3.10 \pm 0.20$ & $55.9 \pm 8.8$ \\
\hline 67 & \begin{tabular}{|l|}
$\begin{array}{l}\text { San Carlos } \\
\text { de Bolivar }\end{array}$ \\
\end{tabular} & $\begin{array}{c}100-150 \\
\mathrm{~mm} \mathrm{~F}\end{array}$ & $1.72 \pm 0.09$ & $5.93 \pm 0.30$ & $1.58 \pm 0.08$ & $10 \pm 5$ & 145 & $3.00 \pm 0.20$ & $32.1 \pm 4.5$ \\
\hline 68 & Pirovano & 4-11 mm P & $1.74 \pm 0.05$ & $3.10 \pm 0.15$ & $1.19 \pm 0.06$ & $15 \pm 5$ & $192 \pm 10$ & $2.48 \pm 0.14$ & $16.6 \pm 3.0$ \\
\hline 69 & Toay & $\begin{array}{c}100-200 \\
\mathrm{~mm} \mathrm{~F}\end{array}$ & $1.95 \pm 0.10$ & $6.97 \pm 0.35$ & $1.85 \pm 0.09$ & $10 \pm 5$ & 75 & $3.20 \pm 0.20$ & $12.8 \pm 1.0$ \\
\hline 70 & Toay & $\begin{array}{c}100-200 \\
\mathrm{~mm} \mathrm{~F}\end{array}$ & $1.91 \pm 0.10$ & $6.57 \pm 0.33$ & $1.70 \pm 0.09$ & $10 \pm 5$ & 105 & $3.20 \pm 0.20$ & $1.1 \pm 0.3$ \\
\hline 71 & $\begin{array}{l}\text { Arroyo El } \\
\text { Perdido }\end{array}$ & 4-11 mm P & $1.58 \pm 0.08$ & $8.41 \pm 0.42$ & $1.92 \pm 0.10$ & 23 & 145 & $2.90 \pm 0.20$ & $37.5 \pm 4.1$ \\
\hline
\end{tabular}




\begin{tabular}{|c|c|c|c|c|c|c|c|c|c|}
\hline No. & location & $\begin{array}{c}\text { grain size } \\
\text { mineral }\end{array}$ & $\begin{array}{l}\mathrm{K} \\
\% \\
\end{array}$ & $\begin{array}{c}\text { Th } \\
\text { ppm }\end{array}$ & $\begin{array}{c}\text { U } \\
\text { ppm }\end{array}$ & $\begin{array}{c}\text { water } \\
\% \\
\end{array}$ & $\begin{array}{c}d_{\operatorname{cosm}} \\
\mathrm{mGy} / \mathrm{a}\end{array}$ & $\begin{array}{c}\mathrm{d}_{\text {tot }} \\
\mathrm{mGy} / \mathrm{a}\end{array}$ & $\begin{array}{c}D_{\text {equ }} \\
\text { Gy }\end{array}$ \\
\hline 72 & $\begin{array}{l}\text { Cochiso/ } \\
\text { Alsina }\end{array}$ & 4-11 mm P & $1.84 \pm 0.05$ & $2.94 \pm 0.15$ & $1.31 \pm 0.07$ & $15 \pm 5$ & $201 \pm 10$ & $2.61 \pm 0.15$ & $13.0 \pm 4.3$ \\
\hline 73 & Carhue W & 4-11 mm P & $1.35 \pm 0.06$ & $7.04 \pm 0.35$ & $1.48 \pm 0.04$ & $15 \pm 5$ & $201 \pm 10$ & $2.75 \pm 0.14$ & $382.9 \pm 6.0$ \\
\hline 74 & Carhue W & 4-11 mm P & $1.49 \pm 0.06$ & $6.02 \pm 0.30$ & $1.53 \pm 0.04$ & $15 \pm 5$ & $188 \pm 9$ & $2.73 \pm 0.14$ & $334.4 \pm 6.4$ \\
\hline 75 & Carhue W & 4-11 mm P & $1.53 \pm 0.04$ & $6.12 \pm 0.30$ & $1.16 \pm 0.05$ & $15 \pm 5$ & $204 \pm 10$ & $2.63 \pm 0.13$ & $56.8 \pm 5.1$ \\
\hline 78 & Grl. Acha N & 100-200 KF & $1.67 \pm 0.08$ & $5.60 \pm 0.28$ & $1.46 \pm 0.07$ & $10 \pm 5$ & 115 & $2.90 \pm 0.20$ & $6.5 \pm 0.6$ \\
\hline 79 & Grl. Acha W & 100-200 KF & $1.82 \pm 0.09$ & $6.10 \pm 0.31$ & $1.71 \pm 0.09$ & $10 \pm 5$ & 105 & $3.20 \pm 0.20$ & $17.1 \pm 1.2$ \\
\hline 80 & Grl. Acha W & $4-11 \mathrm{~mm} P$ & $1.86 \pm 0.09$ & $6.67 \pm 0.33$ & $1.79 \pm 0.09$ & $10 \pm 5$ & 85 & ૩-20 — 0.20 & $16.3 \pm 1.7$ \\
\hline 82 & \begin{tabular}{|l|} 
Mar del Plata \\
Santa Clara \\
d.M. \\
\end{tabular} & 4-11 mm P & $1.28 \pm 0.06$ & $5.92 \pm 0.30$ & $1.72 \pm 0.04$ & $15 \pm 5$ & $204 \pm 10$ & $2.82 \pm 0.14$ & $155.4 \pm 10.0$ \\
\hline 85 & $\begin{array}{l}\text { Mar del Plata } \\
\text { Carnet }\end{array}$ & 4-11 mm P & $1.23 \pm 0.06$ & $5.70 \pm 0.33$ & $1.61 \pm 0.04$ & $15 \pm 5$ & $195 \pm 10$ & $2.67 \pm 0.13$ & $276.3 \pm 33.7$ \\
\hline 86 & $\begin{array}{l}\text { Mar del Plata } \\
\text { Carnet }\end{array}$ & 4-11 mm P & $1.45 \pm 0.07$ & $6.59 \pm 0.33$ & $1.64 \pm 0.04$ & $15 \pm 5$ & $200 \pm 10$ & $2.88 \pm 0.14$ & $154.7 \pm 5.6$ \\
\hline 88 & Mar del Plata & 4-11 mm P & $1.23 \pm 0.06$ & $6.55 \pm 0.33$ & $1.65 \pm 0.04$ & $15 \pm 5$ & $204 \pm 10$ & $2.81 \pm 0.14$ & $45.7 \pm 2.7$ \\
\hline \multicolumn{10}{|c|}{ Fluvial samples representing arid climate } \\
\hline 6 & \begin{tabular}{l|} 
Tte. Pico/Est. \\
San Juan \\
\end{tabular} & 9०-२०० mm Q & & & & & & & \\
\hline 7 & $\begin{array}{l}\text { Filadelfia/ } \\
\text { Madrejon } \\
\end{array}$ & 9०-२०० mm Q & & & & & & & \\
\hline 10 & $\begin{array}{l}\text { Campo } \\
\text { Aroma }\end{array}$ & 90-200 mm Q & & & & & & & \\
\hline 13 & Neuland & 90-200 mm Q & & & & & & & \\
\hline 14 & Neuland & 9०-२०० mm Q & & & & & & & \\
\hline 15 & $\begin{array}{l}\text { Pozo Col./ } \\
\text { Grl.Diaz } \\
\end{array}$ & 90-200 mm Q & & & & & & & \\
\hline 16 & Las Lomitas & 150-200 KF & $0.71 \pm 0.04$ & $3.55 \pm 0.18$ & $0.97 \pm 0.05$ & $15 \pm 5$ & 105 & $1.80 \pm 0.10$ & $21.8 \pm 3.7$ \\
\hline 17 & Las Lomitas & $150-200 \mathrm{KF}$ & $0.82 \pm 0.04$ & $4.62 \pm 0.23$ & $1.24 \pm 0.06$ & $10 \pm 5$ & 130 & $2.00 \pm 0.10$ & $24.1 \pm 0.8$ \\
\hline 18 & Clorinda W & $4-11 \mathrm{~mm} P$ & $1.60 \pm 0.08$ & $17.71 \pm 0.89$ & $5.04 \pm 0.25$ & $15 \pm 5$ & 135 & $5.10 \pm 0.40$ & $14.4 \pm 0.7$ \\
\hline 19 & Clorinda W & 4-11 mm P & $1.37 \pm 0.07$ & $8.43 \pm 0.42$ & $2.22 \pm 0.11$ & $15 \pm 5$ & 140 & $2.80 \pm 0.20$ & $8.2 \pm 0.4$ \\
\hline 21 & $\begin{array}{l}7 \mathrm{~km} \mathrm{~N} \\
\text { Napenay }\end{array}$ & 4-11 mm P & $2.07 \pm 0.10$ & $12.35 \pm 0.62$ & $3.14 \pm 0.16$ & $15 \pm 5$ & 150 & $4.30 \pm 0.30$ & $16.2 \pm 2.4$ \\
\hline \multicolumn{10}{|c|}{ Samples representing humid climate } \\
\hline 8 & La Patria & 9०-२०० mm Q & & & & & & & \\
\hline 9 & $\begin{array}{l}\text { Tte. } \\
\text { Montania }\end{array}$ & 4-11 mm P & & & & & & & \\
\hline 11 & $\begin{array}{l}\text { Transchaco/ } \\
\text { Lag. Negra }\end{array}$ & 4-11 mm P & & & & & & & \\
\hline 12 & $\begin{array}{l}\text { Transchaco/ } \\
\text { Fila. }\end{array}$ & 90-200 mm Q & & & & & & & \\
\hline 20 & $\begin{array}{l}7 \mathrm{~km} \mathrm{~N} \\
\text { Napenay }\end{array}$ & 4-11 mm P & $2.08 \pm 0.10$ & $10.07 \pm 0.50$ & $2.61 \pm 0.13$ & $15 \pm 5$ & 150 & $3.90 \pm 0.30$ & $87.1 \pm 3.8$ \\
\hline 22 & $\begin{array}{l}\text { Grl. Roque } \\
\text { Saenz Peña }\end{array}$ & 4-11 mm P & $2.38 \pm 0.12$ & $11.38 \pm 0.57$ & $2.49 \pm 0.12$ & $20 \pm 5$ & 120 & $3.90 \pm 0.30$ & $117.0 \pm 27.5$ \\
\hline 23 & $\begin{array}{l}\text { Bella Vista } \\
\text { Corrientes }\end{array}$ & $4-11 \mathrm{~mm} P$ & $1.04 \pm 0.05$ & $8.27 \pm 0401$ & $0.07 \pm 0.02$ & $15 \pm 5$ & $198 \pm 10$ & $2.09 \pm 0.12$ & $241.1 \pm 4.1$ \\
\hline 24 & $\begin{array}{l}\text { Bella Vista } \\
\text { Corrientes }\end{array}$ & 4-11 mm P & $1.39 \pm 0.07$ & $5.49 \pm 0.27$ & $1.18 \pm 0.03$ & $15 \pm 5$ & $161 \pm 8$ & $2.30 \pm 0.12$ & $122.4 \pm 6.4$ \\
\hline 25 & $\begin{array}{l}\text { Bella Vista } \\
\text { Corrientes }\end{array}$ & 4-11 mm P & $1.51 \pm 0.06$ & $2.31 \pm 0.12$ & $1.67 \pm 0.06$ & $15 \pm 5$ & $188 \pm 9$ & $2.45 \pm 0.12$ & $90.0 \pm 3.2$ \\
\hline 27 & $\begin{array}{l}\text { Autodromo } \\
\text { Emilia } \\
\end{array}$ & 4-11 mm P & $1.71 \pm 0.08$ & $5.29 \pm 0.26$ & $1.49 \pm 0.07$ & $15 \pm 5$ & $172 \pm 9$ & $2.68 \pm 0.14$ & $258.3 \pm 5.8$ \\
\hline 30 & $\begin{array}{l}\text { Autodromo } \\
\text { Emilia }\end{array}$ & 4-11 mm P & $1.73 \pm 0.08$ & $8.17 \pm 0.40$ & $1.21 \pm 0.06$ & $15 \pm 5$ & $170 \pm 9$ & $2.75 \pm 0.16$ & $128.0 \pm 4.7$ \\
\hline 31 & $\begin{array}{l}\text { Autodromo } \\
\text { Emilia } \\
\end{array}$ & 4-11 mm P & $1.44 \pm 0.09$ & $9.47 \pm 0.57$ & $2.14 \pm 0.11$ & $15 \pm 5$ & $182 \pm 9$ & $4.17 \pm 0.33$ & $133.9 \pm 4.7$ \\
\hline 32 & Felicia & 4-11 mm P & $2.02 \pm 0.12$ & $9.03 \pm 0.54$ & $2.20 \pm 0.11$ & $15 \pm 5$ & $190 \pm 10$ & $3.83 \pm 0.30$ & $132.7 \pm 3.5$ \\
\hline 33 & Felicia & 4-11 mm P & $3.82 \pm 0.23$ & $12.40 \pm 0.74$ & $2.93 \pm 0.15$ & $15 \pm 5$ & $195 \pm 10$ & $5.51 \pm 0.52$ & $86.9 \pm 2.2$ \\
\hline 44 & Arroyo & 4-11 mm P & $2.56 \pm 0.12$ & $4.02 \pm 0.20$ & $2.07 \pm 0.10$ & $15 \pm 5$ & $194 \pm 10$ & $3.38 \pm 0.19$ & \\
\hline 45 & $\begin{array}{l}\text { Diamante/ } \\
\text { Camino al } \\
\text { Balneario } \\
\text { Valle María } \\
\end{array}$ & 4-11 mm P & & & & $15 \pm 5$ & $192 \pm 10$ & & saturation \\
\hline
\end{tabular}




\begin{tabular}{|c|c|c|c|c|c|c|c|c|c|}
\hline No. & location & $\begin{array}{l}\text { grain size } \\
\text { mineral }\end{array}$ & $\begin{array}{l}\mathrm{K} \\
\%\end{array}$ & $\begin{array}{l}\text { Th } \\
\text { ppm }\end{array}$ & $\underset{\mathrm{ppm}}{\mathrm{U}}$ & $\begin{array}{c}\text { water } \\
\%\end{array}$ & $\begin{array}{c}d_{\text {cosm }} \\
\mathrm{mGy/a}\end{array}$ & $\begin{array}{c}d_{\text {tot }} \\
\mathrm{mGy/a}\end{array}$ & $\begin{array}{c}D_{\text {equ }} \\
\text { Gy }\end{array}$ \\
\hline 47 & $\begin{array}{l}\text { Diamante/ } \\
\text { Camino al } \\
\text { Balneario } \\
\text { Valle María }\end{array}$ & 4-11 mm P & $3.18 \pm 0.16$ & $6.16 \pm 0.30$ & $\begin{array}{l}1.15 \pm \\
0.102\end{array}$ & $15 \pm 5$ & $192 \pm 10$ & $3.04 \pm 0.18$ & $104.3 \pm 2.4$ \\
\hline 48 & Larocca & 4-11 mm P & $1.28 \pm 0.06$ & $9.80 \pm 0.49$ & $1.91 \pm 0.05$ & $20 \pm 5$ & 135 & $2.70 \pm 0.20$ & $33.4 \pm 2.9$ \\
\hline 50 & Arrecifes & 4-11 mm P & $1.72 \pm 0.09$ & $7.79 \pm 0.40$ & $1.79 \pm 0.06$ & $15 \pm 5$ & $190 \pm 10$ & $3.23 \pm 0.17$ & $669.4 \pm 8.5$ \\
\hline 51 & Arrecifes & 4-11 mm P & $1.24 \pm 0.06$ & $4.20 \pm 0.21$ & $\begin{array}{c}12706 \pm \\
0.06\end{array}$ & $15 \pm 5$ & $174 \pm 9$ & $2.57 \pm 0.13$ & $408.0 \pm 23.1$ \\
\hline 55 & La Plata & 4-11 mm P & $1.22 \pm 0.06$ & $5.22 \pm 0.25$ & $1.73 \pm 0.05$ & $15 \pm 5$ & $163 \pm 8$ & $2.69 \pm 0.13$ & $1036 \pm 16$ \\
\hline 66 & $\begin{array}{l}\text { Canal } \\
\text { Jauretche }\end{array}$ & 4-11 mm P & $1.75 \pm 0.09$ & $7.51 \pm 0.38$ & $1.84 \pm 0.09$ & $20 \pm 5$ & 145 & $2.90 \pm 0.20$ & $23.0 \pm 1.6$ \\
\hline 76 & Grl. Acha E & 4-11 mm P & $1.26 \pm 0.06$ & $6.74 \pm 0.34$ & $1.73 \pm 0.09$ & $20 \pm 5$ & 100 & $2.30 \pm 0.20$ & $1400 \pm 375$ \\
\hline 77 & Grl. Acha E & 4-11 mm P & $1.33 \pm 0.06$ & $7.67 \pm 0.38$ & $1.40 \pm 0.07$ & $20 \pm 5$ & 125 & $2.40 \pm 0.20$ & $800 \pm 130$ \\
\hline 81 & $\begin{array}{l}\text { Mar del Plata } \\
\text { Santa Clara } \\
\text { d.M. }\end{array}$ & 4-11 mm P & $1.30 \pm 0.06$ & $6.51 \pm 0.33$ & $1.61 \pm 0.04$ & $15 \pm 5$ & $168 \pm 8$ & $2.76 \pm 0.14$ & $148.4 \pm 12.3$ \\
\hline 83 & $\begin{array}{l}\text { Mar del Plata } \\
\text { Santa Clara } \\
\text { d.M. }\end{array}$ & 4-11 mm P & $1.11 \pm 0.06$ & $4.45 \pm 0.22$ & $1.68 \pm 0.04$ & $15 \pm 5$ & $196 \pm 10$ & $2.55 \pm 0.12$ & $265.5 \pm 8.0$ \\
\hline 84 & $\begin{array}{l}\text { Mar del Plata } \\
\text { Camet }\end{array}$ & 4-11 mm P & $0.99 \pm 0.05$ & $4.56 \pm 0.23$ & $1.60 \pm 0.04$ & $15 \pm 5$ & $204 \pm 10$ & $2.46 \pm 0.12$ & $296.7 \pm 7.5$ \\
\hline 87 & Mar del Plata & 4-11 mm P & & & & $15 \pm 5$ & $194 \pm 10$ & & saturation \\
\hline
\end{tabular}

Abbreviations: mineral $P, F$ and $Q: P=$ polymineral $F=$ feldspar; $K F=$ potassium feldspar; $Q=q u a r t z ; K-$ potassium concentration; $U-$ uranium concentration: Th - thorium concentration; water - proposed water concentration of the samples; $d_{\text {cosm }}-$ cosmic dose rate; $d_{\text {tot }}-$ total dose rate (estimated values are given in italics); $D_{\text {equ }}$ - equivalent dose

hills, parabolic dunes and windward hollows of associated dunes. In the southern and central part of the investigated area, aeolian sediments dominate originating from the south-western Andes and the Andes foreland (Fig.1). In the north alluvial loessoid sediments dominate in the extensive fans of the main rivers Río Pilcomayo, Río Bermejo, Río Salado and are often intersected by channel sands.

\subsection{Southern region [Pampa]}

In the south western part of the study area an extensive duricrust platform covers aeolian, fluvial and lacustrine deposits of Late Miocene age (Formación Cerro Azul). This duricrust is incised in east-westerly directions by elongated closed valleys of different extension and depth. Some of them are more than $100 \mathrm{~km}$ long, $10 \mathrm{~km}$ wide and $80 \mathrm{~m}$ deep. The bottom of the troughs is dipping to the east following the general morphological inclination of the surface. Several troughs contain Late Pleistocene (TAPIA, 1935) and Holocene deposits.

According to our understanding they might have been formed by karstification and wind erosion (LORENZ, 2002). A Digital Elevation Model using SRTM data and visualizing the morphology of the valleys and their neighbouring areas is the basis for the reconstruction of these processes (Fig. 2). These loessoid sediments originally extended further to the west and covered a wide area of the actual drainage system of the Río Salado Desaguadero. Accordingly, the karstification and erosion processes possibly already began in the early Pleistocene and has continued to the presence. The duricrust was partly decomposed under temporary humid conditions. Strings of small elongated depressions forming temporary lakes after rainfall were developed. Sediment was washed from the edges into the karst depressions. The lakes dried out during successive dry climatic conditions and accumulated material of the depressions. The exposed loose fine-grained loessoid sediments of the borders were blown out. The material was deposited further to the east as part of the loess cover. These repeated processes facilitated the longitudinal growth and the interconnection of the small blow-out depressions which consequently formed the "Valles Grandes". The direction of these troughs matches the direction of the deflation pattern at the eastern slope and the piedmont of the Andean chains.

In the west where sediments were already eroded, the Río Salado Desaguadero system developed in the late Pleistocene. This river lost its sandy sediment load in a resulting wide flat depression of the western Pampa between the Andean foothills and the duricrust platform. The sand was deflated from the bed of Río Salado Desaguadero system and formed a radial fan of mainly parabolic, linear and star dunes on top of the loessoids, duricrust and loess (Fig. 3).

This Pampean Sand Sea (IRIONDO, 1990b) covers an area of more than $200000 \mathrm{~km}^{2}$. Estimates yielded a very variable thickness of the sand layers up to a maximum of $20 \mathrm{~m}$. The transport was directed to the east turning over northeast to north or even northwest (Fig. 3). The Late PleistoceneHolocene sediment ages increase with rising distance from the source areas. That means that the strength of the westerly winds was larger in the Pleistocene than in the Holocene.

Satellite images show lineations in the loess north of the Pampean Sand Sea which are elongated flat depressions called „bajos“. The depressions are visible due to higher soil humidity and related denser vegetation cover or open water bodies after rainfall. They are important for rain water infiltration and recharge of fresh groundwater in the shallow aquifer which otherwise contains highly saline groundwater (KRUCK, 1976). The depression pattern, morphology and ar- 


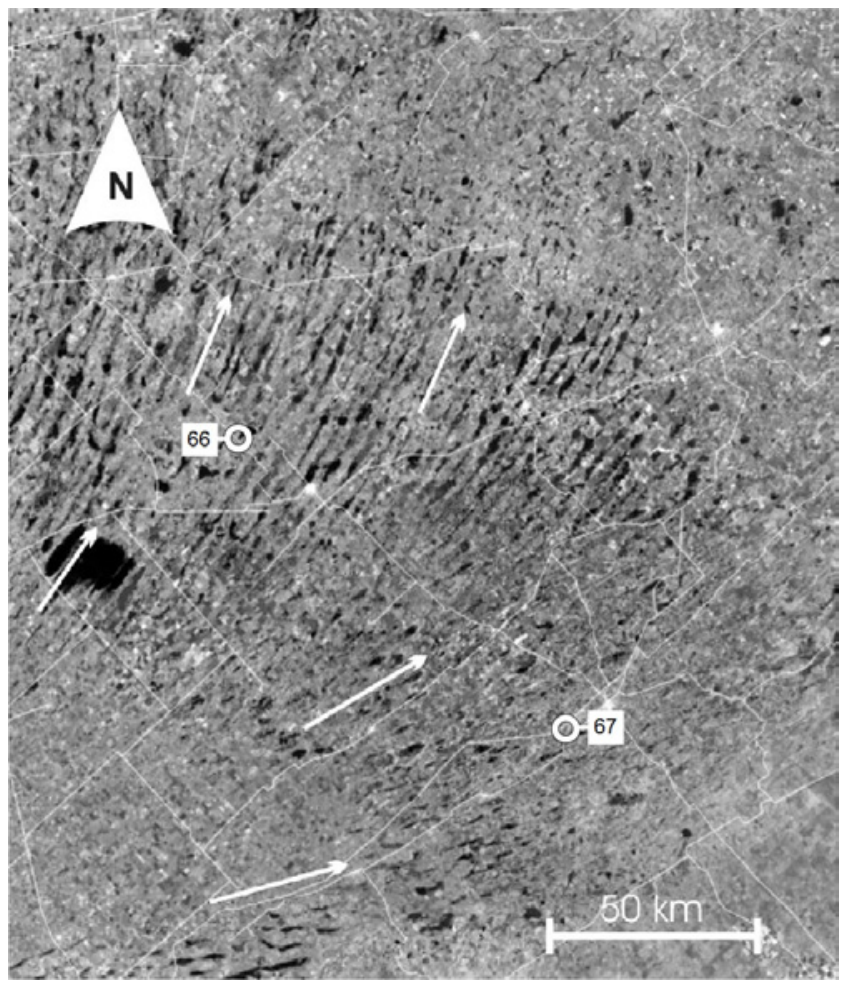

Fig. 3: South western dune field (Pampean Sand Sea; sampling sites Nos. 66 and 67 for orientation), transport direction from southwest; areas with open water due to high groundwater level are dark (Landsat 7 ETM+, true color composite, printed in black \& white).

Abb. 3: Südwestliches Dünenfeld (Pampean Sand Sea - Beprobungsorte Nr. 66 und 67 zur Orientierung): Das Sediment kam von SW; Schwarz repräsentiert oberflächlich anstehende Grundwasser (Landsat 7 ETM+, Echtfarbenbild in schwarz/weiß).

rangement are similar to that of the dune field in the south indicating an aeolian origin. Most likely the „bajos“ are interdune depressions of a "pre-Pampean Sand Sea” dune field. The dunes might have been covered by loess and later the morphology was flattened by erosion. The parallel structures of the "bajos" can be traced over many hundred kilometres in northern direction where they turn to approximately eastwest (Fig. 1). As we did not find any sandy intercalations in the loess outcrops, the old dune system might consist of loess-like fine-grained material or is situated in large depth. Only IRIONDO (1999) describes sand layers in two river valleys and related them to an old megadune system of MIS 4.

Our results support the previous sedimentological and geochemical conception by TerugGi (1957) that the loess generally originated from areas in the southwest or south of the Pampa. We more precisely localized the source in the high Andes (most probably for the finer material), the Andes foothills and the plain southwest of the loess area. All wind features in the southwest of the source area are relatively uniform oriented from west to east. InBAR \& RISSO (2000) describe yardang features by field observation of similar direction about 1000 years old in the Payun Matru volcanic field which we identified on satellite images.

Sedimentological indications of transport by water over longer distances are seldom in the southern part of the Chaco-Pampa Plain. Predominantly clayey lenticular intercalations are of fluvio-lacustrine origin due to their grain size composition and fossil content. Other sediments with- out gradation of the grain size were transported over short distances and became loessoids. Satellite images show that these sediments are located at slopes of elongated depressions without outlet or in floodplains of rivers. They provided evidence for the following diagenetic processes: During dry climate periods rainwater from rare storm events reworked sediments from the slopes of flat depressions. During humid periods this area became inundated and the water sapped new river beds in between. The Rio Salado south of Buenos Aires is such an example where several flat depressions became interconnected.

\subsection{Northern region [Chaco]}

In the northern Chaco-Pampa Plain (northern part of Argentina and western part of Paraguay) extensive alluvial fans of several hundred kilometres with a typical micro-flow pattern are visible on satellite images. The surface is slightly sloping towards the Rio Paraguay-Paraná which represents the base level of the rivers. Extended dark areas of the river fans represent flood loam (Fig. 4). Until recent times, the flood-loam areas hosted dense wood and bush which has been meanwhile widely cleared in order to expand the pasture area for extensive livestock farming.

Sandy river beds are visible as light broad strings on the satellite images as these sandy deposits have high reflection property (Fig. 4). Until recent times the sandy river beds were covered with grass and remote trees. Later on, they were used for agriculture. The pioneer vegetation has been only maintained in environmentally protected areas. In the northwest a dune field extends over more than $10000 \mathrm{~km}^{2}$ in the border region to Bolivia.

The flood loam was deposited by the Chaco rivers (Ríos Pilcomayo, Bermejo, Salado and other small rivers) originating in the Andes mountains. These rivers transported fine grained material and remobilized aeolian sediments from the upper courses. These processes are still going on. After excessive rainfall events in the 1980's, rivers in the Chaco inundated wide areas from the lower to the middle parts of the fans and flood loam was deposited. This material is unsorted due to short distance transport by water and re-deposition processes (flooding) in the flat area. The fine grained sediments sometimes block and displace the river courses. The Río Paraguay-Paraná base level system caused widely extended inundations due to backwater during periods with heavy rainfall as observed during the 1990s. Its tributaries retained more than $200 \mathrm{~km}$ upstream in the Chaco and formed temporary lakes and ponds. OSL ages of the corresponding sediments (Table 2) cluster around the humid Late Glacial-early Holocene period coinciding with the humid Tauca Phase in the High Andes.

In the Late Glacial-Early Holocene period torrential floods of rivers started to engrave the above mentioned channels into the flood loam after short and heavy rainfall events particularly during the long-lasting dry period between 6.4 and about $3.5 \mathrm{ka}$. The succeeding alternating humid and arid phases are well correlated with the up and down of the climate-controlled human settlement fluctuations in the High Andes (Grosjean et al. 2007).

The sand of the northern dune field near the Paraguayan-Bolivian border was dated to Mid-Holocene. It 


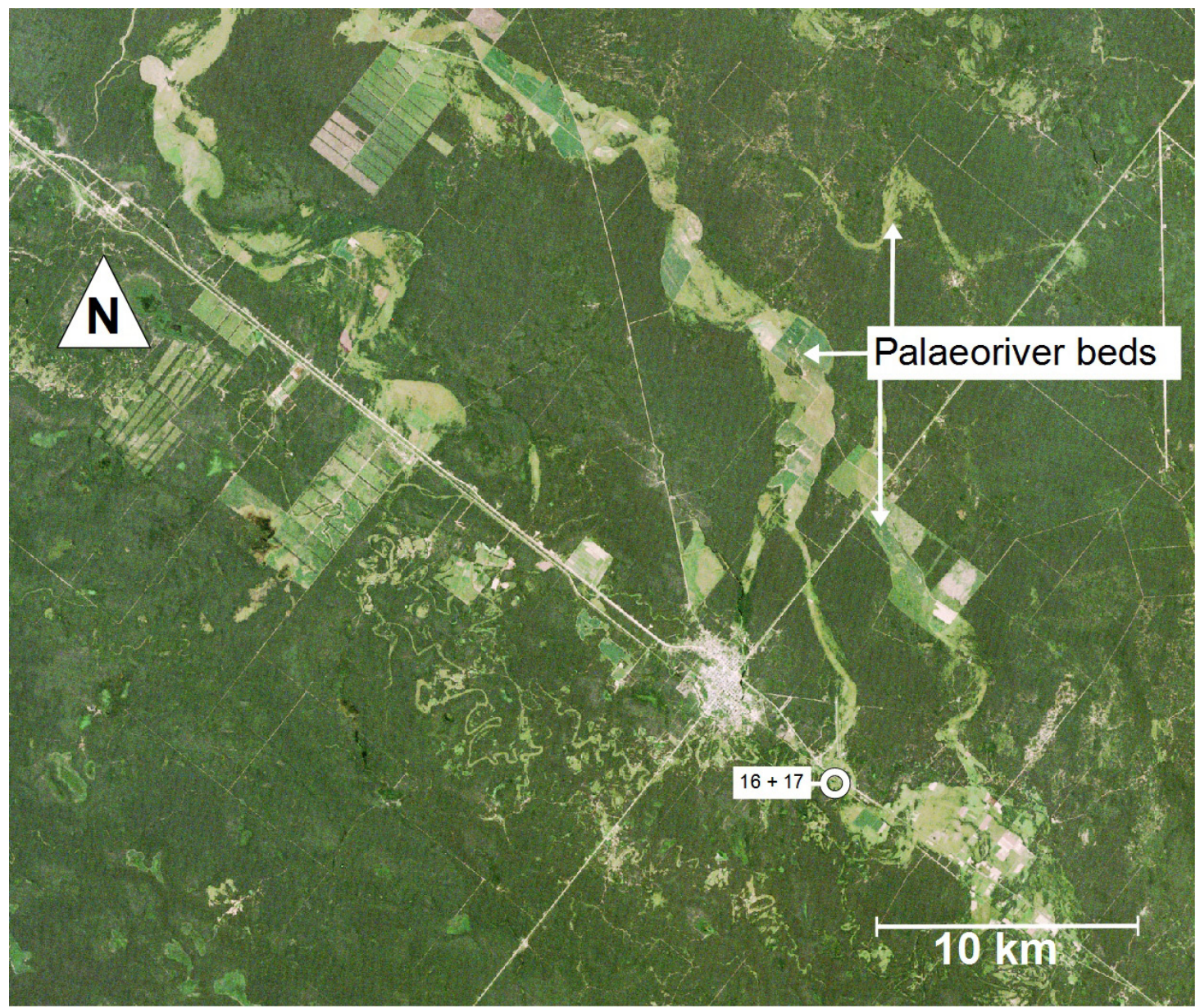

Fig. 4: Palaeoriver pattern of the Río Pilcomayo (sampling sites Nos. 16 and 17 for orientation): Sandy deposits incise flood loam recognizable by intense agricultural use (Landsat 5 TM, true colour composite, 321 RGB).

Abb. 4: Paläoflusssystem des Río Pilcomayo (Probenpunkte Nr. 16 und 17 zur Orientierung): Sandige Ablagerungen eingebettet in Hochflutlehm erkennbar an intensiver landwirtschaftlicher Nutzung (Landsat 5 TM, Echtfarbenbild, 321 RGB).

originates from the Río Parapití which transported sediments to the glacis of the eastern Andes (SERvant et al. 1981). The river continuously dislocated to the north and the sandy deposits were blown out to the south by predominant northerly winds. This process was already recognized by WERDING (1977) and is visible on satellite imagery (BARBOZA et al., 2000).

\subsection{Modern and palaeowind directions}

Aeolian activity is still going on in the Chaco-Pampa Plain. Heavy dust and sand storms and dune movements occurred in periods of pronounced drought in the 18th and 19th centuries and in the thirties and forties of the 20th century. Satellite images from Río Salado (Desaguadero) show recent dust and sand plumes, which provide evidence that the source locations of the dune sands did not change since long and dune formation was relatively continuous (Szelagowski et al., 2004).

The direction of the parabolic dunes of the Pampean Sand Sea in the south west and that of the "Valles Grandes" confirms that strong winds did not change their direction at least since the Pleistocene.

The detected transport and wind direction over the Chaco-Pampa region match with today's occasionally occurring sand and dust storms ("Pampero") in the southern part. They are named "Zonda" in the central and "Nordsturm" (a Mennonite expression in the Chaco) in the northern part, respectively. On June 21, 1993 a dust plume starting from the dry Parapití River bed extended several hundreds of kilometres to the south (NOAA-AVHHR satellite image, from 21st June 1993). A photo taken from a Space Shuttle and published by NASA shows a heavy dust storm over the Altiplano at $26.5^{\circ} \mathrm{S}, 66.5^{\circ} \mathrm{W}$ (1983-09-05; NASA photo ID:STS008-46-937). The dust is blown to the SE into the Chaco region.

\section{Geochronology and palaeoclimate}

We distinguished "arid", "humid" and "cataclysmic flood" samples based on the morphological situation at the sampling site, the facies of the deposits, the kind of fossils, the grain size analysis and the evaluation of satellite images. "Humid" samples are lacustrine, fluvial and loamy materials, fossil bearing deposits and groundwater (PASIG, 2005). Loessoids from the slopes of closed elongated depressions and dune sands represent "arid" periods. Cataclysmic floods during dry periods formed sandy channel deposits. Datable samples which refer to humid conditions were seldom. The reason is that they were deposited in shallow and narrow morphological depressions. Hence, fluvio-lacustrine deposits are generally thin lenticular layers and locally restricted. "Dry material" consists mainly of loessic sediments which 
Tab. 3: Climatic fluctuations in the Pampa-Chaco Plain during the last $60 \mathrm{ka}$. Tab. 3: Klimatische Fluktationen im Pampa-Chaco-Gebiet während der letzten $60 \mathrm{ka}$.

\begin{tabular}{|c|c|}
\hline $\begin{array}{l}\text { Period } \\
\text { [ka BP] }\end{array}$ & $\begin{array}{l}\text { Climatic change and corresponding datable } \\
\text { material }\end{array}$ \\
\hline $60-41$ & $\begin{array}{l}\text { Arid and humid phases [sub-periods cannot be } \\
\text { substantiated] } \\
\text { Loess, fluvio-lacustrine deposits with bones of } \\
\text { macrofauna } \\
\text { low density of dates }\end{array}$ \\
\hline $41-28$ & $\begin{array}{l}\text { Predominant humid phase } \\
\text { Fluvio-lacustrine deposits with bones of } \\
\text { macrofauna, flood loam, groundwater recharge }\end{array}$ \\
\hline 28-16 & $\begin{array}{l}\text { Arid with very weak humid spells } \\
\text { Dunes, loess and flood loam } \\
\text { moderate density of dates }\end{array}$ \\
\hline 16-8.5 & $\begin{array}{l}\text { Humid with an arid interruption } \\
\text { Fluvio-lacustrine deposits, flood loam, channel sand } \\
\text { and loess, dune sands } \\
\text { moderate density of dates }\end{array}$ \\
\hline $8.5-3.5$ & $\begin{array}{l}\text { Arid period with several humid spells } \\
\text { Dune sand, channel sand and few soils } \\
\text { high density of dates }\end{array}$ \\
\hline 3.5-0 & $\begin{array}{l}\text { Dominant humid phase with arid spells } \\
\text { Soils and dune sand as well as channel sands } \\
\text { high density of dates }\end{array}$ \\
\hline
\end{tabular}

usually contain short-distance transported material or is bioturbated. As a consequence the zeroing of the luminescence signal is not guaranteed. All these interferences complicate the non-ambiguous classification of such samples as "arid" material. Based on numerical ages (OSL and ${ }^{14} \mathrm{C}$ ) between $60 \mathrm{ka}$ and $0 \mathrm{ka}$ (MIS 3 to MIS 1) determined within the frame of this study (Table 2) the geomorphological and sedimentological results were recapitulated for the reconstruction of the palaeogeographic and palaeoclimatic evolution of the Chaco-Pampa Plain. Due to the limited number of low precision dates older than $60 \mathrm{ka}$ we omitted their palaeoclimatical interpretation though the corresponding grain size analysis yielded valuable information for the lithologic classification of the corresponding samples in Fig. 1.

The synopsis of the palaeoclimatic interpretation of published and the new dates (Table 3) are compiled in Table 2. The boundaries of the periods may be prone to corrections. Luminescence dates determined with the former conventional methods might be exaggerated due to incomplete bleaching.

\section{Conclusions}

Our interdisciplinary study in the Chaco-Pampa Plain was mainly based on the interpretation of satellite images and many new luminescence dates. It considerably improved the knowledge on the geomorphological, geological and climatic history since $60 \mathrm{ka}$.

The source areas of the loessoid and sandy sediments in the Andes piedmont were more precisely located by means of the wind erosion pattern. The „Valles Grandes“ in the southwest were identified as supplementary source area of loess and loessoid material using the Digital Elevation Model. We deduced the genesis of these valleys from their shape and spatial arrangement. Their formation began with the local decomposition of the duricrust covering the whole area and the exposure of the underlying Upper Miocene loessoid sediments. The latter were mobilized by wind erosion and aeolian transport to the east and northeast. The topographic erosion pattern allowed to reconstruct the wind directions and transport routes of the sediments. Both seem not to have changed since the Pleistocene. In the western erosion areas, westerly winds dominated; further to the east also wind was active to the northeast, north and northwest. The morphology of the loess area is interpreted as covered old dune field consisting of fine sands or loess-like fine sediments. Luminescence dates were obtained from aeolian sandy and loessic sediments representing arid climate. Channel sands were another dated material deposited by cataclystic floods during dominant dry periods. Dunes in the southwest and northwest and channel sands are markers for an intensification of aridity between $8.5-3.5$ ka accompanied by occasional sporadic torrential rainfalls in the mid Holocene.

\section{Acknowledgements}

Many colleagues supported the investigations. We thank V. Baumann, D. Budziak, R. Hoffmann and P. Tchilinguirian for sampling, soil identification and data processing in the frame work of the Segemar/BGR project. We appreciate the steady interest of the director O. Lapido who always supported our activities.

We gratefully acknowledge the constructive discussions and assistance in the selection of sampling sites and field work by J.C. Bertolini, A. Carlini, A. Cione, M.A. Gonzalez, J.I. Noriega, J. San Cristobal, E. Tonni and the assistance in luminescence dating by M. Frechen (Leibniz Institute of Geophysics, Hannover), F. Preusser (University of Cologne) and R. Kuhn (Max-Planck Institute of Nuclear Physics, Heidelberg). We are grateful to both reviewers G.L. Argüello and M. Frechen for valuable improvements.

\section{References}

Abello, A,, Montalvo, C,I, \& Goin, F.J. (2002): Marsupiales del Mioceno Superior de Caleufú (La Pampa, Argentina). - Ameghiniana, 39 (4) 433-422.

Ameghino, F. (1908): Las formaciones sedimentarias de la región litoral de Mar del Plata y Chapadmalán. - Anales del Museo Nacional de Historia Natural, X: 343-428.

Argüello, G,L, Dohrmann, R., Sanabria, J.A. \& Zahn, E. (2010): Genetic implications of a retransported loess profile near Córdoba, $\mathrm{Ar}$ gentina. - Journal of South American Earth Sciences, 29: 642-649; doi:10.1016/j.jsames.2009.12.003.

Barboza, F., Geyh, M., Hoffmann, R., Kruck, W., Medina Netto, A. Merkt, J. \& RoJAs, C. (2000): Soil Formation and Quaternary Geology of the Paraguayan Chaco - thematic Mapping. Geoscientific Cooperation with Latin America. - Zeitschrift für Angewandte Geologie, Sonderheft, 1: 49-54.

Bidegain, J.C. (1991): Sedimentary development, magnetostratigraphy and sequence of events of the Late Cenozoic in Entre Ríos and surrounding areas in Argentina. - Ph.-Thesis: 345 pp; Stockholm.

Fidalgo, F., De Francesco, F., Pascual, R. (1975): Geología superficial de la Llanura Bonaerense. - Relatorio del VI Congreso Geológico Argentino: 103-138; Bahia Blanca.

Frechen, M., Schweizer, U. \& Zander, A.M. (1996): Improvements in sample preparation for the fine grain technique. - Ancient TL, 14: $15-17$. 
Frechen, M., Vanneste, K., Verbeeck, K., Paulissen, E. \& Camelbeeck, T. (2001): The deposition history of the cover sands along the Bree Fault Escarpment, NE Belgium. - Netherlands Journal of Geosciences (Geologie en Mijnbouw), 80 (3-4): 171-185.

Frechen, M., Seifert, B., Sanabria, J. A. \& Argüello, G.L. (2009): Chronology of late Pleistocene Pampa loess from the Córdoba area in $\mathrm{Ar}-$ gentina. - Journal of Quaternary Science, 24: 761-772.

Frenguelli, J. (1957): Neozoico. - Sociedad Argentina de estudios geográficos GAEA, Tomo II (3): 1-218; Buenos Aires.

Fuller, I.C., Wintle, A.G. \& Duller, G.A.T. (1994): Test of partial bleach methodology as applied to the infrared stimulated luminescence of alluvial sediment from the Danube. - Quaternary Geochronology, 13: 539-543.

Geyh, M.A., Grosjean, M., Kruck, W. \& Schotterer,U. (1996): Síncronopsis del Desarrollo Morfológico y Climático del Chaco Boreal y de Atacama en los Últimos 35.000 años AP. - Memorias del XII Congreso Geológico de Bolivia, Tomo, III: 1267-1276; Tarija.

Godfrey-Smith, D.I., Huntley, D.J. \& Chen, W.-H. (1988): Optical dating studies of quartz and feldspar sediment extracts. - Quaternary Science Reviews, 7: 373-380.

Grosjean, M., Calogero, M.S., Tompson, L.G., Nuñez, L. \& Standen, V. G. (2007): Mid-Holocene climate and culture change in the South Central Andes. - In: Anderson, D.G., Masch, K.A \& SAndweiss D.H. (eds.): Climate Change and Cultural Dynamics: A Global Perspective on MidHolocene Transitions: 51-153; Elsevier (Amsterdam).

InBAR, M. \& Risso, C. (2000): Holocene yardangs in volcanic terrains in the southern Andes, Argentina. - Earth Surface Processes and Landforms, 26 (6): 657-666.

IrIONDO, M. (1990a): A late Holocene dry period in the Argentine plains. - Quaternary of South America and Antarctic Peninsula, 7: 197-218.

IRIONDO, M. (1990b): Map of the South American plains-its present state - Quaternary of South America and Antarctic Peninsula, 6: 297-308.

IRIONDO, M. (1997): Letter to the Editor: Comment on A. Prieto's "Late Quaternary Vegetational and Climatic Changes in the Pampa Grassland of Argentina”. - Quaternary Research, 48: 251-252.

IrIONDO, M. (1999): Climatic changes in the South American plains: Records of a continent-scale oscillation. - Quaternary International, 57/58: 93-112.

Iriondo, M., Ceruti, C. שTARdivo, R. (1985): Geomorfología y Quaternario del tramo inferior del Arroyo Feliciano. - Revista de la Asocación de Ciencias Naturales de Litoral, 16: 149-156.

Kemp, R.A., Zárate, M., Toms, P., King, M., Sanabria, J. \& Arguello, G. (2006): Late Quaternary paleosols, stratigraphy and landscape evolution in the Northern Pampa, Argentina. - Quaternary Research, 66: 119-132.

KITTL, E. (1933): Sobre los fenómenos volcánicos y material caído durante la erupción del grupo del "Descabezado" en el mes de abril de 1932 - Anales del Museo de Ciencias Naturales, B. Anales, tomo XXXVII 264-321; Buenos Aires.

KRöHLING, D.M. (1999): Upper Quaternary geology of the lower Carcarañá Basin, North Pampa, Argentina. - Quaternary International, 57/58: 135-148.

KRÖHLING, D.M. \& IRIONDO, M. (1999): Upper Quaternary palaeoclimates of the Mar Chiquita area, North Pampa, Argentina. - Quaternary International, 57/58: 149-163.

KRUCK, W. (1976): Hydrogeological investigations in the Argentine Pampa using satellite imagery. - Geologisches Jahrbuch, A 33: 145-159.

Kunn, R. (2000): Vergleichende Untersuchungen der Optisch (Grün) Stimulierten Lumineszenz und der Thermolumineszenz von Quarz zum Zwecke der Altersbestimmung. - Ph.D.-Thesis, Heidelberg.

Lorenz, W. (2002): The Calcrete Principal (tosca) at the border of the province of La Pampa and Buenos Aires. - Zeitschrift für Angewandte Geologie, 1: 44-51

Melchor, R., Visconti, G., Montalvo,C.I. (2000): Late Miocene calcic vertisols from Central La Pampa, Argentina. - Resúmenes del $2^{\circ}$ Congreso Latinoamericano de Sedimentología y $8^{\circ}$ Reunión Argentina de Sedimentología: 119-120; Mar del Plata, Argentina.

NABEL, P. (1993): The Brunhes-Matuyama Boundary in Pleistocene Sediments of Buenos Aires Province, Argentina. - Quaternary International, 17: 220-227.

Orgeira, M.J. (1987): Estudio paleomagnético de sedimentos del Cenozoico tardio de la costa atlántica bonaerense. - Revista de la Asociación Geológica Argentina, XLII: 362-376.
PASIG, R. (2005): Origen y Dinámica del Agua Subterranea en el noreste del Chaco Sudamericano. - Zeitschrift des Lehr- und Forschungsbereiches Hydrogeologie und Umwelt der Universität Würzburg, 34: $1-103$

Pascual, R., Ortega Hinojosa, E.J.,Gondar, D \& Tonni, E. (1965): Las edades del Cenozoico mamalífero de la Argentina, con especial atención a aquellas del territorio bonaerense. - Anales de la Comisión de Investigaciones Científicas de la Provincia de Buenos Aires, 6: 165-193, La Plata.

Preusser, F. (1999): Lumineszenzdatierung fluviatiler Sedimente - Fallbeispiele aus der Schweiz und Norddeutschland. - Kölner Forum für Geologie und Paläontologie, 3: 1-62.

Preusser, F., Degering, D., Fuchs, M., Hilgers, A., Kadereit, A., Klasen, N., KrbetscheK, M., Richter, D. \& Spencer, J.Q.G. (2008): Luminescence dating: basics, methods and applications. - Eiszeitalter und Gegenwart Quaternary Science Journal, 57 (1-2): 95-149.

Prieto, A.R. (1996): Late Quaternary vegetational and climatic changes in the Pampa Grassland of Argentina. - Quaternary Research, 45 (1): 73-88.

Prieto, A.R. (1997): Reply to the letter to the editor on "Late Quaternary vegetational and climatic changes in the Pampa Grassland of Argentina" by M. Iriondo. - Quaternary Research, 48 (1): 253-256.

SAYAgO, J.M. (1995): The Argentinian neotropical loess: an overview. Quaternary Science Reviews, 14: 755-766.

Servant, M., Fontes, J.-C., Rieu, M. \& Saliège, X. (1981) : Phases climatiques arides holocènes dans le sud-ouest de l'Amazonie (Bolivie). - Compte Rendus de l'Académie des Sciences de Paris, Série II, 292: 1295-1297.

Szelagowski, M., ZÁrate, M. \& Blasi, A.M. (2004): Aspectos sedimentologicos de arenas eolicas del Pleistoceno Tardio- Holoceno de la Provincia La Pampa. Latin America. - Journal of Sedimentology and Basin Analysis, 11 (2): 57-68.

TAPIA, A. (1935): Causas geológicas y consecuencias políticas de los cambios del cauce del Pilcomayo en Formosa. - Anales de la Sociedad Argentina de Estudios Geográficos, IV (2): 235 pp; Buenos Aires, Argentina.

Teruggi, M.E. (1957) : The nature and origin of Argentine loess. - Journal of Sedimentary Petrology, 27 (3): 322-332.

Tonni, E.P., Cione, A.L. \& Figini, A.J. (1999): Predominance of arid climates indicated in the pampas of Argentina during the Late Pleistocene and Holocene. - Palaeogeography, Palaeoclimatology, Palaeoecology, 147: 257-281.

Tonni, E. P., Carlini, A. A., Zurita, A., Frechen, M., Gasparini, G. BudziAK, D. \& KRUCK, W. ( 2005): Cronología y bioestratigrafía de las unidades del Pleistoceno aflorantes en el Arroyo Toropí, provincia de Corrientes, Argentina. - Congreso Brasileiro de Paleontologia, 19. Congreso Latino-Americano de Paleontología de Vertebrados, 6: Edición electrónico de resúmenes; Rio de Janeiro, Brasil.

Tripaldi, A. \& Forman, S.L. (2007): Geomorphology and chronology of Late Quaternary dune fields of western Argentina. - Palaeogeography Palaeoclimatology Palaeoecology, 251(2): 300-320.

VALENCIO, D.A. \& ORgeIRA, M.J. (1983): La magnetostratigrafía del Ensenadense y Bonaerense de la ciudad de Buenos Aires. Parte II. - Revista de la Asociación Geológica Argentina, XXXVIII: 24-33.

Werding, L. (1977): Geomorphologie und rezente Sedimentation im Chaco boreal, Bolivien. - Gießener Geologische Schriften, 12: 429-446.

WiNTLE, A.G. (2008): Luminescence dating: where it has been and where it is going? - Boreas, 37: 471-482.

ZÁrate, M. (2003): The loess record of southern South America. - Quaternary Science Reviews, 22: 1987-2006.

ZÁrATE, M. ¿ BlASI, A. (1990): Consideraciones sobre el origen, procedencia y transporte del loess del sudoeste de la Provincia de Buenos Aires. - International Symposium on Loess, extended abstract: 15-20; Mar del Plata.

Zech, W., Zech, M., Zech,R., Peinemann, N., Morrás, H.J.M., Moretti, L., Ogle, N., Kalim, R.M., Fuchs, M., Schad, P., \& Glaser, B. (2008) Late Quaternary palaeosol records from subtropical $\left(38^{\circ} \mathrm{S}\right)$ to tropical $\left(16^{\circ} \mathrm{S}\right)$ South America and palaeoclimatic implications. - Quaternary International, 196: 107-120. 